\title{
The Impact of Relationship Lending on Bank Loan Process for Korean SMEs ${ }^{*}$
}

\author{
Soo-Young Hwang, Research Fellow, Industrial Bank of Korea \\ Jung-Jin Lee, Professor, Sogang University \\ Yong-Deok Kim ${ }^{* *}$, Research Fellow, Goyang Research Institute
}

\begin{abstract}
$\langle$ Abstract $\rangle$
We investigate the effects of the bank-firm relationships on the decision making process regarding loan application, loan approval, and loan interest rate. To do this, we use data from 2016, and 2017 Surveys of Korea Small Business Finance conducted by Industrial Bank of Korea. We found that a more intense bank-firm relationship increases the likelihood of loan approval. Also, SMEs borrowing from lower number of banks and with more concentrated loans in main bank seem to obtain credit from main bank at lower interest rate than others. But applying for a loan is not related to the bank-firm relationship. This findings suggest that a close bank-firm relationship can reduce information asymmetry problem and alleviate SMEs' credit constraint. Also bank-firm relationships seem to be important in determining the loan interest rate. As a relsult, our findings support that relationship lending has a beneficial effect on the supply side of the Korean SME credit market.
\end{abstract}

Keywords: Credit Constraint; Relationship Lending; Bank-Firm Relationship; SME Credit Market; Information Asymmetry

JEL Classification: G20, G21, G32

* The authors are deeply grateful to the two referees and the editorial committee for their help in improving this paper. The views herein are those of the authors and not those of data provider. Any remaining errors are solely the authors' responsibility.

** Corresponding Author. Address: Goyang Research Institute, Taegeuk-ro 60, Ilsandong-gu, Goyang-si, Gyeonggi-do, 10393, Republic of Korea; E-mail: kyd4462@naver.com;

Tel: +82-31-8073-8319; Fax: +82-31-8073-0711

Received: November 16, 2020; Revised: May 4, 2021 \& June 1, 2021; Accepted: June 21, 2021 


\title{
우리나라 중소기업 대출과정에서 관계금융의 영향분석"
}

\author{
황 수 영 (IBK기업은행 연구위원) \\ 이 정 진 (서강대학교 교수) \\ 김 용 덕 (고양시정연구원 연구위원)**
}

\begin{abstract}
본 연구는 은행-기업 거래관계가 대출신청, 대출승인, 대출금리 결정에 관한 의사결정에 미치는 영향을 알아보고자 한다. 이를 위해 2016년, 2017년 『중소기업금융실태조사』에서 대출수요가 있다고 응답한 3,575 개 기업을 대상으로 분석하였다. 본 연구에서 은행-기업 거래관계의 강도를 측정하는 변수로는 대출거래은행 수, 주거래은행 대출비중, 주거래은행 거래기간을 사용하였다. 분석결과, 첫째, 관계금융 변수는 대출신청과 유의한 결과를 보이지 않았다. 이는 추가 대출신청에 대한 가능성은 기업의 자금수요에 기인하며, 은행-기업의 관계와는 관련성이 없음을 의미한다. 둘째, 은행-기업 관계가 강할수록 대출이 승인될 가능성이 높게 나타났다. 이는 은행-기업 관계가 밀접할수록 정보비대칭성 문제가 개선되어 신용제약이 완화되었음을 의미한다. 셋째, 대출거래은행 수가 적을수록, 대출이 한 은행에 집중되어 있을수록 대출금리가 더 낮았다. 이상의 결과에서 우리는 한국 중소기업 대출시장의 공급측면에서 관계금융의 편익효과가 있음을 확인할 수 있었다. 따라서 자금조달이 어렵고, 조달비용이 높은 중소기업에게 관계금융은 중요한 정책적 대안으로 활용될 수 있다고 하겠다.
\end{abstract}

핵심 단어 : 신용제약, 관계금융, 은행-기업 관계, 중소기업 대출시장, 정보비대칭성

JEL 분류기호: G20, G21, G32

* 논문을 검토해 주신 두 분의 심사위원과 편집위원회의 도움으로 논문의 완성도를 높일 수 있게 된 것에 대해 감사드립니다. 본 연구결과는 저자들의 견해로서 자료제공 기관과는 무관하며, 남아있을 수 있는 어떠한 오류도 저자들의 책임임을 밝힙니다.

** 연락담당 저자. 주소: 경기도 고양시 일산동구 태극로 60, 고양시정연구원, 10393;

E-mail: kyd4462@naver.com; Tel: 031-8073-8319; Fax: 031-8073-0711. 


\section{1. 서론}

우리나라 국민경제에서 중요한 역할을 담당하고 있는 중소기업에 대해 필요한 자금을 적기에 공급하는 것은 안정적인 경제성장을 견인하기 위한 효과적인 방법이다. 그러나 이 과정에서 중소기업의 경우 대기업에 비해 객관적이고 신뢰할만한 정보의 부족 등으로 인해 정보비대칭 문제가 발생하고, 이를 극복하기 위해 금융기관은 담보를 요구하거나 신용이 낮은 중소기업에게 대출을 제한하게 된다. 이러한 신용할당은 중소기업의 금융접근성을 떨어뜨리고, 나아가 기업의 투자 및 고용을 제약하여 기업의 성장에 부정적 영향을 미칠 수 있다(Evans and Jovanovic, 1989).

중소기업의 신용제약을 완화하는 방안의 하나로 관계금융(relationship lending)1)이 중요하게 다루어진다. 은행은 중소기업과 장기간의 관계형성을 통해 중소기업의 상환이력, 거래실적 등의 정보를 축적하게 되고, 이를 대출 의사결정에 활용함에 따라 정보비대칭 문제를 줄일 수 있다 (Diamond, 1991). 이처럼 기존연구에서는 정보비대칭 문제를 완화하고 기업의 금융 접근성을 높이는 관계금융의 편익효과들이 보고되고 있다(Petersen and Rajan, 1994, 1995; Berger and Udell, 1995; Lee and Hwang, 2013).

본 연구의 목적은 관계금융이 신용제약에 어떤 영향을 미치는가를 알아보는데 있다. 구체적으로 대출신청, 대출승인, 대출금리 결정 등 대출의 전 과정에서 관계금융의 역할을 알아보는 것이다. Chakravarty and Yilmazer(2009)는 은행과 차입자 사이의 관계의 효과는 대출과정의 각 단계에서 다르게 작용할 수 있다고 주장하였다. 일례로 은행의 대출승인 의사결정은 상대적으로 유연할 수 있지만 대출금리는 시스템에 의해 산출되기 때문에 조정의 여지가 상대적으로 적다. 즉 은행의 대출금리 결정은 차입자와 은행 사이의 밀접한 관계형성을 통해 축적한 연성정보(soft information)에 의하기 보다는 차입자의 거래실적, 신용등급, 담보 등 계량적 수치에 의해 결정될 가능성이 높다. 이처럼 관계금융의 효과가 대출과정의 각 단계별로 다르게 나타날 수 있으므로, 대출과정을 대출신청 단계, 대출승인 단계, 대출금리 결정 단계로 구분하여 분석할 필요가 있다. 따라서 본 연구는 이러한 Chakravarty and Yilmazer(2009)의 연구주제와 방법론을 국내에 적용하여 은행-기업 간 밀접한 관계형성이 중소기업의 자금조달 가능성을 높이고, 차입금리를 낮추는지, 혹은 그렇지 않은지를 알아보고자 한다.

기존연구에서는 일반적으로 대출승인에 대한 결정요인을 분석할 때 대출신청 기업만을 분석대상으로 하여 단순 프로빗모형(simple probit model)을 활용한다. 그러나 은행의 대출승인 여부의 선택과정은 기업의 대출신청 여부의 선택과정과 관련이 있을 수 있다는 점에서 자기 선택성을 내재하고 있다(Cenni et al., 2015). 즉 대출승인 확률은 기업이 대출신청을 하였다는 전제하에 구할 수 있는 조건부 확률의 특성이 있음에도 불구하고 대출신청 기업만을 대상으로 분석할 경우 대출을 신청하지 않은 기업들이 체계적으로 배제됨으로써 표본선택편의(sample selection bias)의 문제가 발생한다. 이 경우 추정된 회귀계수는 편의된 값을 가지며, 추론된

1) Udell(2008)에 따르면 관계금융이란 차입자와 포괄적 거래를 장기적으로 계속함으로써 얻어지는 독점적 연성정보에 주로 의존하는 대출형태라고 정의하였다. 
The Impact of Relationship Lending on Bank Loan Process for Korean SMEs

인과관계를 전체 중소기업 모집단으로 일반화할 수 없게 된다. 이를 해결하기 위해 본 연구의 실증분석에서는 표본선택을 고려한 이변량 프로빗 모형(bivariate Probit model with sample selection)을 이용하였다.

한편 대출금리 결정 단계에서도 단순 OLS 추정은 대출승인 기업만을 모형에 포함하게 되어 대출금리 결정에 대한 관계금융의 효과를 과대평가할 가능성이 높다. 또한 은행의 대출금리 결정은 차입자가 대출을 신청하고, 은행이 대출신청을 승낙하는 2 가지 조건을 모두 만족해야 관찰가능한 조건부 기대값이므로, 이중선택모형(double selection model)을 이용하여 분석하였다. 첫 번째 단계에서는 중소기업의 대출신청 선택 여부를 추정하고, 두 번째 단계에서는 은행의 대출승인 선택 여부를 추정하고, 세 번째 단계에서는 대출금리 결정요인을 분석한다.

본 연구는 2016년, 2017년 『중소기업금융실태조사』2개년치 자료를 이용하여 우리나라 중소기업금융에 있어서 관계금융의 활용정도를 살펴보고자 한다. 그동안 우리나라에서 관계 금융에 대한 실증연구는 관련 자료가 충분하지 않아 활발하게 이루어지지 못한 측면이 있다. 그러나 다행스럽게도 최근 $\mathrm{IBK}$ 경제연구소에서 우리나라 중소기업의 금융이용 실태와 관련하여, 풍부한 정보를 포함하고 있는 『중소기업금융실태조사』2를 수행함에 따라 이를 활용하여 종합적인 분석을 할 수 있게 되었다. 기존의 학술연구나 정책보고서들은 중소기업금융의 공급측면 (대출승인, 대출금리 결정)에 초점을 맞춘데 반해 수요측면(대출수요, 대출신청)에 대해서는 소홀한 면이 있었다. 이러한 점에서『중소기업금융실태조사』는 중소기업금융의 공급 및 수요 측면을 모두 살펴볼 수 있는 귀중한 자료라고 할 수 있다.

본 연구의 주요 분석결과는 다음과 같다. 첫째, 관계금융 변수는 대출신청과 유의한 결과를 보이지 않았다. 이는 대출신청의 경우 관계의 정도가 아니라 해당 연도의 자금수요에 기인한 결과라고 생각된다. 둘째, 은행-기업 거래관계가 강할수록 대출이 승인될 가능성이 높게 나타났다. 이는 은행-기업 관계가 밀접할수록 정보비대칭성 문제가 개선되어 신용제약이 완화되었음을 의미한다. 셋째, 관계금융이 대출금리에 미치는 영향을 분석한 결과, 대출거래은행 수가 적을수록, 주거래은행 대출비중이 높을수록 대출금리가 낮게 나타났다. 결론적으로 국내 중소기업 대출시장의 수요측면에서는 관계금융의 영향이 나타나지 않았으나, 공급측면에서는 중소기업 에게 개선된 금융접근성과 더 낮은 대출금리를 제공하는 관계금융의 역할을 확인할 수 있었다.

이하 연구의 순서를 요약하면 다음과 같다. 제 2 장에서는 관계금융에 대한 기존연구들을 살펴본다. 제 3 장에서는 연구방법을 살펴보고, 제 4장에서는 자료 및 변수정의에 대해 설명한다. 제 5 장에서는 실증분석의 결과를 제시한다. 마지막으로 제 6 장 결론에서는 분석의 결과를 종합하고 시사점을 논의한다.

\section{2. 선행연구}

중소기업은 외부자금조달을 주로 은행을 통한 간접금융에 의존하고 있다. 은행을 통한

2) IBK경제연구소 홈페이지(research.ibk.co.kr) 참조. 
한국증권학회지 제50권 5호 (2021)

자금조달은 중소기업의 성장과 발전을 위해 필수적이다(Berger and Udell, 1998). 그런데 일반적으로 중소기업은 대기업에 비해 정보 불투명성이 상대적으로 높고, 기업 내부정보(private information)를 수집하는데 있어 더 많은 비용이 소요된다(Ang, 1991). 높은 정보 비대칭성은 은행들로 하여금 신용할당을 야기하여 중소기업의 금융접근성을 제한한다(Stiglitz and Weiss, 1981).

정보비대칭 문제는 은행이 중소기업과 지속적인 관계를 형성하고 그 과정에서 획득한 연성정보를 대출 의사결정 과정(대출 승낙·거절, 대출금리 결정)에 이용함으로써 극복할 수 있다고 알려져 있다(Ongena and Smith, 2000; Elyasiani and Goldberg, 2004). 은행은 정보비대칭의 해소에 따른 이익의 일부를 중소기업에게 이전할 경우, 중소기업은 개선된 금융접근성과 더 나은 대출조건의 이익을 향유할 수 있게 된다. 이처럼 관계금융이 차입자와 은행 양측 모두에게 긍정적인 효과로 나타날 때 이를 관계금융의 편익효과라고 한다.

Boot and Thakor(1994)는 관계금융의 편익효과에 대한 이론적 기초를 제공하였다. 그들은 대출 거래관계의 길이, 차입금리, 담보와 같은 요인들을 이용하여 대출시장을 모형화하고, 대출 거래관계가 길수록 차입금리가 낮아지고 담보요구를 줄인다고 주장하였다. Petersen and Rajan(1994)과 Berger and Udell(1995)은 1988년과 1989년 사이에 미국의 연방준비제도 (FRB)와 중소기업청(SBA)에 의해 수행된 『미국 중소기업금융조사(NSSBF)』자료를 이용하여 실증분석한 결과, Boot and Thakor(1994)의 주장을 지지하는 결과를 얻었다. 즉 은행과의 밀접한 관계형성은 자금조달 가능성을 높이고, 차입금리를 낮추는 반면, 다수은행과의 거래관계는 자금조달 가능성을 줄이고, 차입금리를 높인다고 보고하였다. 이러한 효과는 대출가격 보다는 대출한도에서 더 뚜렷한 효과를 보였다. Bharath et al.(2011)은 주거래은행 대출비중이 높을수록 차입금리 스프레드는 10 15bp 낮았으며, 주거래은행으로부터 차입한 기업이 주거래은행이 아닌 은행으로부터 차입한 기업에 비해 1 2\% 더 많은 대출금액을 확보할 수 있음을 발견하였다. 국내연구로서 Lee and Hwang(2013)은 실제 A은행의 중소기업 대출자료를 이용하여 분석한 결과, $\mathrm{A}$ 은행과 거래기간이 길고 거래은행 수가 적을수록 $\mathrm{A}$ 은행은 기업에게 더 낮은 대출금리를 제공함을 발견하고, 우리나라 중소기업 대출시장에서 관계금융의 편익효과가 작용하고 있음을 주장하였다.

이에 반해 기업에 대한 독점적 정보 획득을 통해 기업에 비해 우위의 협상력을 갖게 되어 강한 은행-기업 관계가 기업에게 오히려 불리한 결과를 가져올 수도 있다. 이를 관계금융의 비용효과라고 한다. Sharpe(1990)는 관계금융의 비용효과에 대한 이론적 기초를 제공하였다. 그는 정보 비대칭성 관점에서 기업의 차입을 모형화하였는데, 만일 한 은행이 차입자와 반복적인 거래를 통해 경쟁은행에 비해 정보우위에 서게 된다면 궁극적으로는 왜곡된 경쟁의 결과를 낳게 된다고 주장하였다. 즉 은행은 대출가격을 결정할 때 잠김효과(lock-in effect)를 예상하고, 경제적 지대를 가격에 반영하게 되는데, 초기단계에서는 할인된 대출가격을 제공하지만 장래에는 대출가격을 인상하게 된다고 한다. Rajan(1992)은 거래관계가 있는 은행이 차입기업의 경영을 감시하고, 차입기업의 사업 프로젝트에 관한 의사결정에 영향을 미칠 수 있다고 하였다. 그는 이와 같은 기업경영에 관한 은행의 영향이 관계금융의 비용으로 작용함을 확인하였다. Degryse 
The Impact of Relationship Lending on Bank Loan Process for Korean SMEs

and van Cayseele(2000)는 벨기에 은행에 의해 실행된 18,000개의 대출자료 분석을 통해 주거래은행 거래기간과 금융비용 사이에는 양의 관계가 있음을 발견하고 유럽 은행시스템의 경제적 지대추구 행위를 보고하였다. 그러나 다른 금융상품을 추가로 구매하였을 때는 차입금리가 하락한다고 하였다. Hernández-Cánovas and Martínez-Solano(2010)는 스페인의 자료를 이용하여 분석한 결과, 주거래은행 거래기간과 대출시장 집중도의 증가는 차입자의 유연성을 감소시키고, 더 높은 대출비용을 초래한다고 보고하였다. 국내연구로서 Kim and Kim(2007)은 국내 상장사 502개 기업을 대상으로 분석한 결과, 은행과의 밀접도가 높은 기업일수록 자금 가용성이 낮고 차입금리가 높게 나타나, 관계금융이 기업의 비용요소로 작용하고 있음을 보고하였다.

한편 새로운 접근방법으로 관계금융의 효과를 분석한 선행연구들이 있다. 그들은 대출공급 측면과 대출수요 측면을 동시에 분석대상으로 삼았으며, 여러 단계의 대출과정이 수요자와 공급자의 연속적인 선택과정으로 자기선택성이 내재되어 있음을 고려함으로써 관계금융의 연구분야를 확장하였다(Chakravarty and Yilmazer, 2009; Cenni et al., 2015; Cole and Sokolyk, 2016). Chakravarty and Yilmazer(2009)는 1993, 1998, 2003년 『미국 중소기업금융조사 $(\mathrm{NSSBF}) 』$ 자료를 이용하여 분석한 결과, 대출을 신청할지 말지에 대한 차입자의 결정과 은행의 대출승인/거절 의사결정에서 거래관계가 중요함을 발견하였다. 즉 더 많은 은행과 거래할수록 대출신청을 할 가능성이 더 높았으며, 은행과 거래관계가 있는 기업3)이 그렇지 않은 기업에 비해 대출이 승인될 가능성이 $13.5 \%$ 더 높게 나타났다. 그런데 대출금리에 대한 거래관계의 효과는 경제상황별로 다르게 나타났다. 은행과 기존의 거래관계를 가진 기업들은 거래관계가 없는 기업들에 비해 경기확장기 동안 더 낮은 금리를 확보한 반면 경기후퇴기 동안에는 이러한 관계를 발견할 수 없었다. Cenni et al.(2015)은 이탈리아 기업을 대상으로 분석한 결과, 은행-기업 관계는 대출신청 여부와는 유의한 관계를 보이지 않았지만, 대출승인 여부와는 유의한 양의 관계를 발견하였다.

\section{3. 연구방법}

본 연구는 은행-기업 관계가 대출신청 기업의 대출승인과 대출금리 결정에 어떤 영향을 미치는지를 알아보는데 그 목적이 있다. 본 연구에서 대출 실행과정은 다음의 3 단계 의사결정으로 구성되어 있다고 가정한다. 첫째, 차입자는 대출을 신청할지 아닐지를 결정한다. 둘째, 은행은 식별과정(screening process)을 통하여 대출을 승인할지 거절할지를 결정한다. 마지막으로, 대출승인에 대한 조건부로 은행은 대출금리를 결정한다. 대출승인 결정은 차입자가 대출을 신청하였을 때만 관찰가능하고, 대출금리는 대출 신청자가 대출신청을 결정하고 은행이 대출을 승인하였을 때만 관찰가능하기 때문에 비확률선택표본의 단일방정식 모형으로는 다양한 단계의 효과를 파악하기 곤란하다. 따라서 본 연구에서는 Chakravarty and Yilmazer(2009)를

3) Chakravarty and Yilmazer(2009)는 은행과의 거래관계를 기존대출 보유여부(더미변수)로 측정하였다. 
따라 다음의 3 개의 방정식에 의해 설명되는 이중선택모형(double-selectivity model)을 이용한다.

대출신청 방정식:

$$
y_{1}= \begin{cases}1 & \text { if } y_{1}^{*}=Z^{\prime} \gamma_{1}+\epsilon_{1}>0 \\ 0 & \text { otherwise }\end{cases}
$$

대출승인 방정식:

$$
y_{2}= \begin{cases}1 & \text { if } y_{1}=1 \text { and } y_{2}^{*}=Z^{\prime} \gamma_{2}+\epsilon_{2}>0 \\ 0 & \text { if } y_{1}=1 \text { and } y_{2}^{*}=Z^{\prime} \gamma_{2}+\epsilon_{2} \leq 0\end{cases}
$$

여기서 $y_{1}^{*}$ 는 대출신청에 대한 차입자의 결정을 나타내는 잠재변수(latent variable), $y_{2}^{*}$ 는 대출 승인에 대한 은행의 결정을 나타내는 잠재변수이다. $Z$ 는 독립변수 벡터, $\gamma_{1}, \gamma_{2}$ 는 모수벡터이다. 오차항 $\epsilon_{1}, \epsilon_{2}$ 는 평균 0 , 분산 1 의 다변량 정규분포를 따른다고 가정한다. $\operatorname{Cov}\left(\epsilon_{1}, \epsilon_{2}\right)=\rho$ 이다. 만일 $y_{1}^{*}>0$ 이면, 차입자는 대출을 신청하며 $\left(y_{1}=1\right)$, 그렇지 않다면, 대출을 신청하지 않는다 $\left(y_{1}=0\right)$. 또한 $y_{2}^{*}>0$ 이면, 차입자는 대출이 승인되며 $\left(y_{2}=1\right)$, 그렇지 않다면, 대출이 거절된다 $\left(y_{2}=0\right)$. 본질적으로 $y_{1}=1$ 일 때만 $y_{2}$ 가 관찰된다. 따라서 만일 차입자가 대출신청을 하지 않는다면 $\left(y_{1}=0\right)$, 대출이 승인되었는지 혹은 거절되었는지를 관찰할 수 없다.

대출금리결정 방정식 :

$$
y_{3}=X^{\prime} \beta+u
$$

여기서, $y_{3}$ 는 관측된 대출금리이며, $X$ 는 독립변수 벡터, $\beta$ 는 모수 벡터, $u$ 는 오차항이다. 대출 금리는 차입자가 대출을 신청하고, 대출신청 조건부로 대출이 승인될 때(즉, $y_{1}=y_{2}=1$ )만 관측될 수 있다. 만일 식 (3)의 오차항이 식 (1) 혹은 식 (2)의 오차항과 서로 상관된다면, OLS 추정치는 표본선택에 의해 편의될 수 있다(Heckman, 1979).

이중선택 기법(double selection technique)은 식 (3)에서 2개의 잠재적 선택편의를 제거하는데 유용하다고 알려져 있다(Poirier, 1980; Lee, 1983).

$$
E\left[y_{3} \mid y_{1}=1, y_{2}=1\right]=X^{\prime} \beta+\sigma_{1 u} \lambda_{1}+\sigma_{2 u} \lambda_{2}
$$

여기서 $\sigma_{i u}=\operatorname{Cov}\left(\epsilon_{i}, u\right)$, 그리고 $\lambda_{i}=\frac{\phi\left(Z \gamma_{i}\right) \Phi\left(\frac{Z \gamma_{j}-\rho Z \gamma_{i}}{\sqrt{1-\rho^{2}}}\right)}{B\left(Z \gamma_{i}, Z \gamma_{j}, \rho\right)}, i, j=1,2$ 이고 $j \neq i$ 이다. $\phi(\bullet)$ 와 $\Phi(\bullet)$ 는 각각 표준정규확률밀도함수(pdf), 표준정규누적분포함수 $(\mathrm{cdf})$, 그리고 $B(\bullet)$ 는 이변량 표준정규분포함수이다. 만일 $\sigma_{1 u}$ 와 $\sigma_{2 u}$ 가 둘 다 0이 아니라면 식 (4)의 기대값은 $X^{\prime} \beta$ 와 동일하지 않다. 따라서 중도절단 표본(censored sample)으로 식 (4)를 단일선택 규칙으로 구한 최소자승 추정치는 모형설정 오류 편의(specification error bias)를 야기할 것이다(Heckman, 1976). 
The Impact of Relationship Lending on Bank Loan Process for Korean SMEs

식 (4)를 추정하기 위해 Heckman(1976)의 2단계 추정절차가 이용된다. 첫 번째 단계는 $\gamma_{1}$, $\gamma_{2}$ 의 추정치를 얻기 위해 최우추정법(maximum likelihood estimation)을 이용하여 식 (1), (2)의 Probit 모형을 추정한다. 식 (1), (2)에서 구한 $\hat{\gamma}_{1}, \hat{\gamma}_{2}, \hat{\rho}$ 의 모수추정치를 이용하여 inverse $\operatorname{Mill}$ 's ratio $\left(\hat{\lambda}_{1}, \hat{\lambda}_{2}\right)$ 를 구한다. 두 번째 단계에서는 1 단계에서 구한 $\hat{\lambda}_{1}, \hat{\lambda}_{2}$ 를 금리결정방정식의 독립변수에 포함하여 사용하고, 이를 최소자승법(OLS)으로 추정한다(식 (4)). 이렇게 구한 2단계 추정량은 일치추정량이다.

한편 오차항의 정규분포를 가정하는 Heckman의 2 단계 추정모형에서는 1 단계의 선택방정식과 2 단계의 결과방정식에 동일한 설명변수들을 사용할 경우 다중공선성과 관련된 식별문제가 발생하게 된다(Cameron and Trivedi, 2005). 이 경우 선택방정식에 포함된 변수 중 최소한 하나는 결과방정식에 제외되어야 한다는 제약(exclusion restriction)에 따라 선택방정식의 종속변수와는 밀접한 관계가 있으면서 결과방정식의 종속변수와는 관계가 없는 변수를 선택 방정식에 도구변수(instrumental variables)처럼 포함시키는 방안을 강구해야 한다. 본 연구 에서의 표본선택 이변량 프로빗모형에서는 Cenni et al.(2015)이 식별변수로 사용한 연구개발 집약도(R\&D)를 대출신청 모형(선택방정식)에는 포함하고, 대출승인 모형(결과 방정식)에는 제외하고 분석하였다.4) 또한 이중선택모형에서는 연구개발집약도(R\&D)와 수도권 소재 여부 (MSA)를 대출신청 및 대출승인 모형(선택방정식)에는 포함하고, 대출금리 결정 모형(결과 방정식)에는 제외하고 분석하였다.

\section{4. 자료 및 변수정의}

\section{1 자료}

본 연구는 실증분석을 위해 IBK경제연구소에서 전국의 4,500개 비금융 중소기업을 대상으로 2016년과 2017년에 실시한 『중소기업금융실태조사』5) 자료를 이용하였다. 조사대상은 전산업의 종사자 수 5 인 이상 300 인 미만의 중소기업으로 구성된다. 조사항목은 은행이용 실태, 신규자금 조달 현황, 자금결제 현황, 자금운용 현황, 경영상황 및 자금전망 등이다. 본 연구에서는 동 조사항목을 이용하여 대출신청, 대출승인, 대출금리 등 종속변수와 대출거래은행 수, 주거래은행 거래기간 등 은행-기업 간 관계를 정의한다.

본 연구에서는 2016년, 2017년 『중소기업금융실태조사』2개년치 자료를 통합(pooling)하여

4) Sartori(2003)는 식별성을 개선하기 위해서는 결과방정식에서 적어도 하나의 변수를 제거하고 분석할 것을 제시하였다. 한편 최근의 일부 연구에서는 결과방정식에서 하나의 변수를 제거(exclusion restriction)하지 않고도 강건성에 큰 문제가 없는 추정방법을 고려하고 있다(Klein and Vella, 2010).

5) 본 조사의 표집틀은 각각 2013,2014 년 전국 사업체 조사결과를 사용하였다. 표본은 업종(KSIC 중분류)과 종사자규모(1 6규모)를 층화변수로 하는 층화계통추출법(stratified systematic sampling method)을 사용하여 추출되었다. 이 때 층별 목표 변동계수(CV)는 $5 \%$ 이며, 종사자 수 50 인 이상인 층에서는 층별로 계산된 표본크기를 그대로 배분하고, 종사자 수 50 인 미만인 층에서는 모집단 크기에 제곱근 비례배분을 하였다. IBK경제연구소 홈페이지(research.ibk.co.kr) 참조. 
사용한다.6)『중소기업금융실태조사』2016년판과 2017년판의 조사대상 연도는 각각 2015년과 2016년이다. 또한 본 연구에서는 다양한 분석을 위해 각 응답기업의 해당 연도 재무정보를 대응시켰다. 기업특성에 사용된 기업 재무자료는 한국기업 데이터(주) 자료를 이용하였으며, 기업의 은행별 대출자료는 전국은행연합회 신용정보 자료를 이용하였다. 그 결과 설문에 응답한 총 9,000개 중소기업 중에서 식별번호의 누락으로 재무자료를 확보할 수 없는 73 개 기업은 분석에서 제외되었다.

\section{2 변수정의}

\subsection{1 신용제약의 측정과 종속변수}

본 연구에서 신용제약 중소기업은 신규대출을 신청하였으나 은행에 의해 전부 혹은 일부 대출이 거절된 중소기업으로 정의하며, 비신용제약 중소기업은 신규대출을 신청하고, 은행에 의해 대출이 전부 승인된 중소기업으로 정의한다. 이에 따라 본 연구에서는 『중소기업금융실태 조사』설문지에서 다음 5 가지 질문에 대한 중소기업의 응답을 이용한다.

(1) 귀사는 은행에서 신규대출7)을 신청한 적이 있습니까? (yes, no) (yes에 응답하였을 경우 (3)으로 이동, no에 응답하였을 경우 (2)로 이동)

(2) 은행에서 신규대출을 신청하지 않은 이유는 무엇입니까? (a, b)8)

a. 자금이 필요하지 않아서

b. 자금이 필요하지만 신청해도 대출되지 않을 것 같아서

(3) 귀사는 은행에서 신규대출을 받은 적이 있습니까? (yes, no) (no에 응답하였을 경우 (4)로 이동)

(4) 귀사가 은행에 신청한 신규대출이 거절된 적이 있습니까? (yes, no)

(5) 신규대출 받은 자금의 담보 형태별 평균 대출금리 수준은 어느 정도입니까?

(담보대출 : $\%$, 신용보증서담보대출 : $\%$, 신용대출 : $\%)$

본 연구에서 위 설문항목 (1), (3)번 질문에 모두 yes라고 응답한 경우 '신용제약이 없다'고 정의하고, (1), (4)번 질문 모두에 yes라고 응답한 경우 '신용제약이 있다’고 정의한다. 설문항목 (2)번에서 $b$ 를 선택한 경우는 대출수요는 있지만 대출이 되지 않을 것 같아 대출신청을 포기한 경우로서 이를 대출낙담자(discouraged borrowers)로 정의한다. 이러한 대출과정을 <그림 $1>$ 에 요약하였다.

6) 본 연구에서 이용하고 있는 『중소기업금융실태조사』는 패널조사가 아니라 매년 층화계통추출법 (stratified systematic sampling method)으로 작성된 자료이기 때문에 원론적으로는 표본가중치 (sampling weights)를 사용하여 연도별로 분석해야 한다. 하지만 2016년 조사의 표본가중치 이용이 불가능하고 연도별로 추정하였을 경우 표본의 크기가 작아 우도함수가 수렴하지 않았다. 이에 본 연구에서는 불가피하게 2개년치 자료를 통합하여 분석하였다.

7) 신규대출은 기간연장, 대환, 재약정을 제외한 순수 신규대출을 의미한다.

8) 설문문항의 보기에는 “c. 은행대출 이외의 다른 방식으로 자금조달, d. 기타”도 있는데 이에 응답한 기업(475개)은 은행 대출수요가 없는 것으로 처리하여 분석에서 제외하였다. 
〈그림 1〉 대출진행 과정(Cole and Sokolyk, 2016: 59)

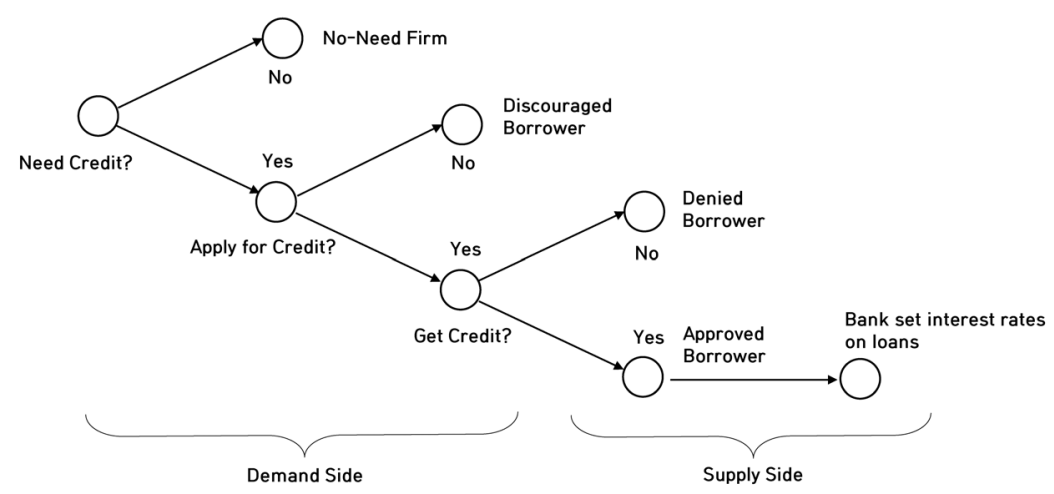

본 연구에서는 위의 대출과정을 반영하여 대출신청 여부, 대출승인 여부, 대출금리를 종속 변수로 사용한다. 먼저 대출신청 여부(Applied)는 대출을 신청하였을 경우 1 , 아니면 0 의 값을 가지는 더미변수이다(위 (1)번 문항).

대출승인 여부(Approved)는 은행에 의하여 대출이 승낙되었을 경우 1 , 아니면 0 의 값을 가지는 더미변수이다(위 (3)번 문항).

대출금리(Loan Rate)는 응답기업이 실제로 2015년, 2016년 중 은행에서 신규로 받은 대출의 금리이다. 본 연구에서는 대출금리 값을 실태조사 자료(위 (5)번 문항)에서 구해서 쓰고 있는데, 만일 신규대출이 여러 건인 경우 어떻게 처리해야 하는지는 중요한 문제이다. 동일한 성격의 대출이 여러 건인 경우에는 설문지에서 담보형태별로 대출금리를 평균해서 작성하게끔 유도 하였으며, 대출을 다른 담보종류별로 중복으로 받았을 경우에는 그 중 하나의 금리를 사용하고 해당 담보종류를 더미변수로 표시하여 설명변수에 포함하였다. 그런데 신용대출 금리는 기업의 신용등급에 따라 정해지고, 담보대출 금리는 담보가치에 따라 결정되며, 신용보증서담보대출 금리는 보증비율에 따라 결정된다. 일반적으로 담보대출과 신용보증서담보대출은 거래관계가 없는 은행에서도 신규 대출이 어렵지 않기 때문에 신용대출이 좀 더 관계금융의 영향력 하에 있을 것으로 생각된다. 따라서 신용대출, 담보대출, 신용보증서담보대출을 중복으로 받은 경우 신용대출 금리를 우선적으로 적용하였으며, 그 다음으로 담보대출 금리, 신용보증서담보대출 금리 순으로 금리를 적용하였다. 중복대출의 경우 대출금리 적용 예시는 다음과 같다.

〈표 1〉 중복대출의 경우 대출금리 적용 예시

\begin{tabular}{lll}
\hline 담보형태별 신규대출 종류 & \multicolumn{1}{c}{ 적용금리 } & 더미변수 처리 \\
\hline 신용 & 신용대출금리 & Unsecured loan $=1$, Secured loan $=0$ \\
신용, 담보 & 신용대출금리 & Unsecured loan=1, Secured loan $=0$ \\
신용, 신용보증서 & 신용대출금리 & Unsecured loan=1, Secured loan $=0$ \\
신용, 담보, 신용보증서 & 신용대출금리 & Unsecured loan=1, Secured loan=0 \\
담보 & 담보대출금리 & Unsecured loan=0, Secured loan=1 \\
담보, 신용보증서 & 담보대출금리 & Unsecured loan $=0$, Secured loan=1 \\
신용보증서 & 신용보증서담보대출금리 & Unsecured loan=0, Secured loan $=0$ \\
\hline
\end{tabular}




\subsection{2 관계금융 변수}

본 연구에서는 은행-기업 거래관계의 강도를 측정하는 변수로 선행연구에서 가장 많이 사용하는 대출거래은행 수, 주거래은행 대출비중, 주거래은행 거래기간을 사용한다(Petersen and Rajan, 1994; Berger and Udell, 1995; Cole, 1998; Degryse and Ongena, 2001; Elsas, 2005; Kim and Kim, 2007; Lee, 2009; Lee and Hwang, 2013; Cenni et al., 2015).

한편 거래관계의 밀접도는 기업과 은행이 느끼는 실질적인 관계의 정도를 정확히 측정할 수 있는 대리변수이어야 한다. 그런데 이들 변수들이 거래관계의 밀접도와 관련성이 적거나 단순히 거래의존도를 나타내는 정보비대칭 변수일 가능성도 의심해볼 수 있다. 이는 우리나라가 유럽의 지역금융기관과는 달리 시중은행의 경우 지역밀착형 관계를 기대하기 어려운 구조에 기인한다. 이러한 한계에도 불구하고 본 연구에서 이들 변수들을 사용한 것은 자료 확보의 제약으로 인해 아직까지 이를 대체할 만한 변수를 찾기 힘들기 때문이다.

선행연구와 마찬가지로 본 연구에서는 기업의 대출거래은행 수가 적을수록 결속관계가 강하다고 간주한다. 다수은행 거래관계는 단일은행 거래관계에 비해 은행-기업 간 결속관계가 약할 수 있으므로 신용제약 확률이 더 높을 수 있다(Dewatripont and Maskin, 1995; von Rheinbaben and Ruckes, 2004). 반대로 다수은행 거래관계의 형성은 은행사이에 경쟁을 초래하여 각 개별은행의 독점지대 추구행위를 제한할 수 있기 때문에 기업의 요구조건을 은행이 더 잘 수용하게 된다는 주장도 있다(Rajan, 1992). 따라서 대출 거래은행 수가 많을수록 신용제약이 심한지 아닌지에 대한 일방적인 결과를 기대할 수 없다. 본 연구에서 대출거래은행 수는 설문 조사의 질문(“대출거래를 하고 있는 은행은 총 몇 개 입니까?”)에 대한 응답값을 사용하여 정의한다.

기존연구에서는 대출거래를 하나의 은행과 하고 있거나 혹은 다수은행과 대출거래가 있더라도 대출이 소수은행에 집중될수록 결속관계가 강한 것으로 본다. 이에 본 연구에서는 주거래은행 대출비중 변수를 관계금융의 변수 중 하나로 채택하였다. 그런데『중소기업금융실태조사』에서는 주거래은행 대출비중을 묻고 있지 않아 본 연구에서는 전국은행연합회 신용정보자료를 이용하여 주거래은행을 해당 기업의 최다대출은행으로 정의하고, 주거래은행 대출비중은 해당 기업의 총은행 대출액 중에서 최다대출은행의 대출액이 차지하는 비중으로 계산하였다.

또한 일반적으로 은행-기업 거래기간이 길수록 결속관계가 강한 것으로 여긴다. 주거래은행 거래기간이 길수록 정보의 비대칭성이 보다 효과적으로 극복될 수 있을 것이기 때문에 신용제약 확률이 더 낮을 것으로 기대할 수 있다. 이에 반해, 주거래은행 거래기간이 긴 기업들이 규모가 작거나 정보가 불투명한 기업일 경우 주거래은행에 결속되어 홀드업 문제(hold-up problem)에 직면할 가능성도 있다. 그럴 경우 이들 중소기업들은 낮은 대출한도, 높은 대출금리 등 불리한 대출조건에 놓이게 된다. 이에 본 연구에서는 연단위로 주거래금융기관과의 거래기간을 묻고 있는 『중소기업금융실태조사』항목을 이용하여 주거래은행 거래기간을 정의하였다(“주거래 은행과 거래기간은 얼마나 되셨습니까?” 년 그개월). 단, 『중소기업금융실태조사』에서는 주거래금융기관을 대출거래를 주로 하거나 대출이 없을 경우 예금, 신용카드, 급여이체 등의 금융거래를 주로 하는 금융기관으로 정의하고 있다. 이 때 금융기관에는 시중, 지방, 특수, 외국은행 국내지점 외에도 저축은행, 신용협동기구 등이 포함된다. 따라서 본 연구에서는 은행-기업 
The Impact of Relationship Lending on Bank Loan Process for Korean SMEs

거래관계 분석에 한정하고 있으므로 주거래금융기관을 저축은행, 신용협동기구 등 제 2 금융권 이라고 응답한 기업을 표본에서 제외하였다.

본격적인 논의에 앞서, 우리는 본 연구에서 사용하고 있는 주거래은행 대출비중과 주거래은행 거래기간 변수 간 주거래은행의 정의가 다르다는 점을 짚고 넘어가고자 한다. 설문조사에서는 주거래은행이 어디인지 구체적인 은행명으로 답할 것을 요구하지 않고, 시중은행, 특수은행, 지방은행, 외국은행 중 택하게 되어 있기 때문에 주거래은행 대출비중의 은행과 주거래은행 거래 기간의 은행이 다를 수 있다. 즉, 설문조사에서 응답기업이 생각하는 주거래은행과 해당 기업이 실제로 최다 대출을 받은 은행이 일치하지 않을 수 있다. 자료의 한계상 현재 이 부분의 수정은 불가능하기 때문에 본 연구에서는 이 점을 감안하여 분석 결과를 해석하고자 한다.

\subsection{3 통제변수}

(1) 대출특성

은행대출 보유여부(Bank Loan)는 기존에 은행대출을 보유하고 있다면 1, 아니면 0의 값을 가지는 더미변수이다. 은행대출은 주거래은행으로부터 차입한 대출뿐만 아니라 주거래은행이 아닌 은행으로부터 차입한 대출 등 은행으로부터 차입한 모든 대출금을 포함한다. 자료는 전국은행연합회 신용정보 $\mathrm{DB}$ 를 이용하여 구하였다.

비은행금융기관대출 보유여부(Nonbank Loan)는 비은행금융기관9)에서 신규대출을 받은 적이 있다면 1 , 아니면 0 의 값을 가지는 더미변수이다. 비은행금융기관대출 보유여부는 설문 조사의 질문(“비은행금융기관에서 신규대출을 받은 적이 있습니까?”)에 대한 응답값을 사용하여 정의한다.

정책자금대출10) 보유여부(Policy Fund Loan)는 정부·지방지치단체 등에서 신규로 정책자금 대출을 받은 적이 있다면 1 , 아니면 0 의 값을 가지는 더미변수이다. 정책자금대출 보유여부는 설문조사의 질문(“신규로 정책자금을 받은 적이 있습니까?”)에 대한 응답값을 사용하여 정의한다.

한편 신규대출의 특성을 통제하기 위해 담보종류(신용/담보/신용보증서)를 묻는 더미변수11) 들을 대출금리 결정 단계에서만 설명변수로 포함한다. 왜냐하면 이미 신규대출을 받은 기업들에 대해서만 담보와 대출금리를 물었기 때문에 대출신청/승인 단계에서는 설명변수로 사용할 수 없다.12) 그런데 만일 대출을 담보종류별로 중복으로 받았을 경우에는 신용대출, 담보대출, 신용보증서담보대출 순으로 하나의 금리를 종속변수로 사용하고 해당 금리의 담보를 더미변수로

9) 비은행금융기관은 보험사, 증권사, 카드사, 캐피탈사, 저축은행, 새마을금고, 신협, 지역농·수·축협 등 제 2 금융권을 의미한다.

10) 정책자금대출이란 중소기업 금융지원을 위해 정부, 지방자치단체, 유관기관 등에서 제공하는 자금 및 신용보증서를 말하며, 공제조합 등 사업자단체, 조합에서 제공하는 자금(예: 중소기업중앙회 공제사업기금대출 등)은 제외한다.

11) 설문조사의 질문, “신규대출을 받았다면, 담보별 대출금리 수준은?"에 대한 응답값을 사용한다.

12) 만일 대출신청과 대출승인 단계에서도 설명변수에 포함하고자 한다면, 대출신청 시 신용대출을 신청하였는지, 담보대출을 신청하였는지, 대출이 거절되었다면 신용대출이 거절되었는지, 담보대출이 거절되었는지 등의 질문이 있었다면 가능하지만, 아쉽게도 이러한 질문이 포함되어 있지 않다. 
한국증권학회지 제 50 권 5호 (2021)

표시하였다. 여기서 범주는 3 개이지만 2 개의 더미변수만을 사용해야 하므로 신용대출과 담보대출 변수만 설명변수에 포함한다.13) 신용대출(Unsecured Loan)은 신규대출이 신용대출이면 1 , 아니면 0의 값을 가지는 더미변수이고, 담보대출(Secured Loan)은 신규대출이 담보대출이면 1 , 아니면 0 의 값을 가지는 더미변수이다.

(2) 기업특성

기업규모는 신용제약에 중요한 영향을 미칠 수 있다. Cenni et al.(2015)에 따르면 대기업에 비해 중소기업의 신용제약 확률이 더 높다고 하였다. 따라서 백만원 단위로 표시한 매출액을 로그변환하여 기업규모의 대용변수로 사용하였다. 규모가 큰 기업이 작은 기업에 비해 정보 투명성이 높은 것이 일반적이므로 기업규모는 정보투명성의 대용변수가 될 수 있다.

정보투명성의 또 다른 대용변수는 기업업력이다. 일반적으로 업력이 오래된 기업일수록 그들의 성과를 파악하기에 용이한 실적자료를 축적해 두었을 것이기 때문에 정보가 투명하다고 할 수 있다. 또한 Diamond(1991)에 따르면 더 오랜 기간 사업을 영위한 기업일수록 혹독한 창업 초기를 거친 후 충분한 평판자본(reputational capital)을 생성하였기 때문에 기업업력은 대출 승인에 영향을 미친다고 주장하였다. 기업업력은 설립일로부터 관측년도 말일까지의 경과일수를 연단위로 환산한 후 로그변환하여 사용하였다.

유형자산(Tangible asset)은 총자산대비 유형자산 비중으로 나타낸다. 유형자산은 중소기업의 담보제공 능력의 대용변수로 사용한다. 유형자산 비중이 높은 기업일수록 신용제약 확률이 낮고 대출금리도 낮을 것으로 기대된다.

기업의 리스크를 나타내는 변수로 레버리지(Leverage)를 사용하였다. 레버리지는 자산대비 부채 비율로 나타낸다. 레버리지가 높은 기업일수록 리스크가 높을 것이므로 추가대출과는 음의 관계, 대출금리와는 양의 관계가 기대된다.

기업의 성장성을 나타내는 변수로 매출액 증가율(Sales growth)을 사용하였다. 매출액 증가율은 매출액의 연평균 증가율로 계산한다. 성장성이 높은 기업일수록 자금수요가 많을 것으로 기대된다. Binks and Ennew(1996)는 기업의 성장성이 금융접근성에 음의 영향을 미친다고 주장하였다. 반면 Canton et al.(2013)은 성장성이 금융접근성과 양의 관계를 가진다고 주장하였다.

수익성은 은행대출 접근에 양의 영향을 미친다고 알려져 있다. 왜냐하면 현금흐름이 양호한 기업들은 대출상환 불능 위험이 낮기 때문이다. Bougheas et al.(2006)은 수익성이 높은 기업들이 수익성이 낮은 기업들에 비해 은행대출 접근이 더 쉽다는 것을 보였다. 기업의 수익창출 능력을 나타내는 변수로 $\mathrm{ROA}$ 를 사용하였다.

현금 보유가 양호한 기업일수록 신용제약 가능성이 낮을 것으로 예상된다. 현금은 총자산대비 현금 및 현금등가물의 비율로 계산한다.

혁신성은 중소기업의 신용제약에 영향을 미치는 또 다른 요인으로 언급되고 있다. Guiso(1998),

13) 만약 범주의 개수대로 더미변수를 만들면, 회귀분석에서 더미변수의 함정(Dummy Variable Trap)에 걸려 회귀분석이 수행되지 않기 때문에 더미변수의 개수는 범주의 개수보다 하나 작아야 한다. 
The Impact of Relationship Lending on Bank Loan Process for Korean SMEs

Atzeni and Piga(2007) 등은 연구개발집약도가 낮은 기업들이 자금조달에 더 큰 어려움에 직면함을 발견하였다. 반면 혁신성은 높은 위험성과 관련이 있기 때문에 혁신적인 기업들은 은행대출 접근이 더 어렵다는 주장도 있다(Freel, 2007). 혁신성의 대용변수로는 Guiso(1998)에 따라 매출액대비 연구개발비 비중을 사용하였다. 여기서 연구개발비는 지출 시 무형자산화하는 부분과 비용으로 처리하는 부분의 합으로 계산되는 데 자산처리 부분은 주석상의 당기 개발비 취득분을, 비용처리 부분은 손익계산서와 제조원가명세서상의 경상개발비를 사용하였다.

신용위험(credit risk)을 통제하는 추가적인 기업특성 변수로 저위험등급을 설명변수에 포함 한다. 저위험등급(Low Risk)은 기업의 신용등급이 $\mathrm{AAA} \sim \mathrm{BBB}-$ 이면 1, 아니면 0의 값을 가지는 더미변수이다. 기업 신용등급 자료는 한국기업데이터(주)의 자료를 사용하였으며, 이때 기업 신용등급은 개별기업 고유의 신용위험을 평가한 '차주등급'14)을 의미한다.

(3) $\mathrm{CEO}$ 특성

$\mathrm{CEO}$ 의 특성도 신용제약과 밀접한 관련이 있을 것으로 기대된다. 먼저 $\mathrm{CEO}$ 의 나이가 너무 어릴 경우 사업경험이 부족하기 때문에 은행 대출심사자에 의해 대출이 거절될 가능성이 높다. 그래서 $\mathrm{CEO}$ 의 나이를 나타내는 더미변수를 포함하였다. $\mathrm{Y} 30$ 은 30 대 이하, $\mathrm{Y} 60$ 은 60 대 이상을 나타낸다.

$\mathrm{CEO}$ 의 성별도 신용제약에 중요한 영향을 미치는 요인으로 언급된다. Cavalluzzo and Cavalluzzo(1998)의 연구에서는 미국 중소기업자료15)를 이용하여 분석한 결과, 중소기업 CEO의 성별에 따른 대출승인 확률은 큰 차이가 없다고 주장하였다. 반면에 Muravyev et al.(2009)의 연구에서는 세계 34 개국 14,108 개 기업자료16)를 이용하여 분석한 결과, 여성이 경영하는 기업의 대출승인 확률이 남성이 경영하는 기업보다 $5 \%$ 더 낮고, 대출금리는 $0.5 \% \mathrm{p}$ 더 높다고 보고하였다. $\mathrm{CEO}$ 의 성별을 나타내는 변수인 Female은 여성이면 1, 남성이면 0의 값을 가지는 더미변수이다.

(4) 대출시장

은행 간 경쟁은 기업의 외부차입에 긍정적 혹은 부정적 영향을 미칠 수 있다(CarboValverde et al., 2009). 시장지배력가설(the market power hypothesis)에 따르면, 시장지배력이 증가 할수록 대출공급이 제한되고 대출금리가 높아져 결국에는 신용제약이 심화된다고 주장한다(Boot and Thakor, 2000). 이에 반해 정보가설(the information hypothesis)에 따르면, 독점적 시장지배력은 정보비대칭 문제를 해결할 인센티브를 제공하기 때문에 대출공급은 증가하게 되고, 그에 따라 신용제약이 완화된다고 주장한다(Petersen and Rajan, 1995). 즉 시장지배력은 은행들로 하여금 기업들과 관계형성을 통해 상대적으로 위험하고 정보가 불투명한 기업들에게

14) 금융기관에서는 차주의 부도 위험을 평가한 '차주 등급'과 개별 여신에 대한 손실위험과 관련하여 특정 거래 요인을 평가하는 '여신 등급'의 이원화된 체계로 운영하고 있다.

15) 미국 FRB에 의해 5년마다 수행되는 ${ }^{\circledR}$ National Survey of Small Business Finance(NSSBF)』의 기업자료를 이용하였다.

16) 세계은행과 EBRD에 의해 수행된 『2005 Business Environment and Enterprise Performance Survey(BEEPS)』설문자료는 34 개국 14,108 개 기업의 자료를 포함하고 있다. 
부과해야 할 금리 프리미엄을 포기하는 대신 장기적으로는 정보지대 추구를 허용한다는 것이다. 본 연구에서는 시장지배력의 대용치로 영업점 수로 측정한 HHI(Herfindahl-Hirschman Index)를 사용하였다.17)

$$
\mathrm{HHI}=\sum_{i=1}^{N} s_{i}^{2}
$$

위 식 (5)에서 $s_{i}$ 는 해당 지역내 '은행 영업점 수’를 기준으로 한 은행 $i$ 의 시장점유율(해당 지역내 은행들의 총영업점 수 대비 은행 $i$ 의 영업점 수 비중)을 나타내고, $N$ 은 해당 지역내 은행들의 수를 나타낸다. 시장점유율 산정 시 지역은 신우편번호 앞 세 자리(postal zone)를 기준으로 전국을 242 개 지역으로 나누어 계산하였다. 이렇게 구한 $\mathrm{HHI}$ 는 0 과 1 사이의 값을 가지며, 경쟁적일수록 0 에 가까운 값을, 독점적일수록 1 에 가까운 값을 갖는다.

지역적 위치에 따른 신용제약의 차이를 분석하기 위해 수도권 소재 여부(MSA)를 설명변수에 포함하였다. 수도권 소재 여부(MSA)는 기업이 서울특별시, 인천광역시, 경기도에 소재하면 1 , 아니면 0 의 값을 가지는 더미변수이다.

지역별 경제력 차이에 따른 신용제약의 영향을 알아보기 위해 1 인당 지역내총생산(lnGDP)18)을 설명변수에 포함하였다. 1 인당 지역내총생산은 통계청에서 발표하는 16 개 광역자치단체19)의 2015,2016 년도 자료를 천원단위로 나타낸 값에 로그변환하여 사용하였다. 일반적으로 은행의 신용공급은 경기 순행적인 특징을 가지기 때문에 경제력이 좋은 지역은 기업들의 신용제약 확률이 낮지만, 경제력이 좋지 않은 지역은 기업들의 신용제약 확률이 높을 수 있다.

(5) 산업특성 등

본 연구에서는 산업별 특성이 종속변수에 미치는 영향을 통제하기 위해 산업더미를 모형에 포함하였다. 산업더미는 한국표준산업 대분류 기준에 따랐다. 또한 더미변수를 제외한 모든 자료는 표본 분포의 양극단 $1 \%$ 에 대해 윈저화기법 20$)$ 을 적용하였다. 지금까지 설명한 분석대상 변수는 <표 2>에 요약하였다.

17) 본 연구에서처럼 대출시장 집중도의 대용변수로서 영업점 수 기준 $\mathrm{HHI}$ 를 사용한 기존 연구들로는 Boot and Thakor(2000), Elsas(2005), Degryse and Ongena $(2005,2007)$ 등이 있다. 미국의 많은 연구들에서는 예금 점유율 기준 $\mathrm{HHI}$ 를 주로 사용하지만, Fisher(2000)에 따르면 '영업점 수 HHI'는 '예금 $\mathrm{HHI}$ '와 매우 높은 상관관계를 가지기 때문에 어느 방법을 사용하더라도 결과값에 미치는 영향은 거의 동일하다고 한다.

18) 1 인당 지역내총생산이란 각 시·도내에서 경제활동별로 얼마만큼의 부가가치가 발생되었는가를 나타내는 경제지표이다. 쉽게 말해 시도별 GDP라고 할 수 있다.

19) 16 개 광역자치단체는 서울특별시, 인천광역시, 부산광역시, 대구광역시, 대전광역시, 울산광역시, 강원도, 경기도, 경남, 경북, 전남, 전북, 충남, 충북, 제주특별자치도이다.

20) 윈저화(Winsorization)기법은 이상치의 왜곡된 영향을 줄이기 위해 분포의 상하 $\alpha \%$ 이내에서 그 값을 초과하는 경우에는 그에 해당하는 값을 부여하는 방법이다. 예를 들어, $90 \%$ Winsorization은 5th percentile 미만의 값들은 5th percentile 값으로 대체하고, 95th percentile을 초과하는 값들은 95th percentile 값으로 대체한다. 
The Impact of Relationship Lending on Bank Loan Process for Korean SMEs

〈표 2〉 변수정의

\begin{tabular}{|c|c|c|}
\hline & 변수명 & 변수정의 \\
\hline 종속변수 & $\begin{array}{l}\text { Applied } \\
\text { Approved } \\
\text { Loan Rate }\end{array}$ & $\begin{array}{l}\text { 기업이 대출을 신청하면 } 1 \text {, 아니면 } 0 \\
\text { 기업이 신청한 대출이 승인되면 } 1 \text {, 아니면 } 0 \\
\% \text {, 신규대출 금리 }\end{array}$ \\
\hline 관계금융 변수 & $\begin{array}{l}\text { Number of banks } \\
\text { Main bank's debt share } \\
\text { Relationship duration }\end{array}$ & $\begin{array}{l}\text { 개, 대출거래은행 수 } \\
\text { 최다대출은행 대출액/총은행 대출액 } \\
\text { 년, 주거래은행 거래기간 }\end{array}$ \\
\hline 대출특성 & $\begin{array}{l}\text { Unsecured loan } \\
\text { Secured loan } \\
\text { Bank Loan } \\
\text { Nonbank Loan } \\
\text { Policy Fund Loan } \\
\end{array}$ & $\begin{array}{l}\text { 신규대출이 신용대출이면 } 1 \text {, 아니면 } 0 \\
\text { 신규대출이 담보대출이면 } 1 \text {, 아니면 } 0 \\
\text { 은행 대출을 보유하고 있다면 } 1 \text {, 아니면 } 0 \\
\text { 비은해ㅇㅡㅡㅁ융기관대출을 보유하고 있다면 } 1 \text {, 아니면 } 0 \\
\text { 정책자금대출을 보유하고 있다면 } 1 \text {, 아니면 } 0\end{array}$ \\
\hline 기업특성 & $\begin{array}{l}\text { lnSale } \\
\text { Tangible asset } \\
\text { Leverage } \\
\text { lnFage } \\
\text { Sales growth } \\
\text { ROA } \\
\text { Cash } \\
\text { R\&D } \\
\text { Low Risk }\end{array}$ & $\begin{array}{l}\ln (\text { 매출액 }) \\
\text { 유형자산/총자산 } \\
\text { 총부채/총자산 } \\
\ln (\text { 기업 업력), 업력은 연단위로 측정 } \\
\text { 연매출액 증가율 } \\
\text { 당기순이익/총자산 } \\
\text { 현금 및 현금등가물/총자산 } \\
\text { 연구개발집약도=연구개발비/매출액 } \\
\text { 기업의 신용등급이 } \mathrm{BBB}^{-} \text {이상이면 } 1 \text {, 아니면 } 0\end{array}$ \\
\hline $\mathrm{CEO}$ 특성 & $\begin{array}{l}\text { Y30 } \\
\text { Y60 } \\
\text { Female }\end{array}$ & $\begin{array}{l}\mathrm{CEO} \text { 의 나이가 } 30 \text { 대 이하이면 } 1 \text { 아니면 } 0 \\
\mathrm{CEO} \text { 의 나이가 } 60 \text { 대 이상이면 } 1 \text {, 아니면 } 0 \\
\mathrm{CEO} \text { 의 성별이 여성이면 } 1 \text {, 아니면 } 0\end{array}$ \\
\hline 대출시장특성 & $\begin{array}{l}\text { HHI } \\
\text { MSA } \\
\operatorname{lnGDP} \\
\end{array}$ & $\begin{array}{l}\text { Herfindahl-Hirschman Index, 영업 점 수 기준 } \\
\text { 수도권(서울, 인천, 경기)에 소재하면 } 1 \text {, 아니면 } 0 \\
\ln (1 \text { 인당 지역내총생산) }\end{array}$ \\
\hline 산업특성 & Industry Dummy & 산업더미, 한국표준산업분류(KSIC) 대분류 기준 \\
\hline
\end{tabular}

\section{5. 실증분석 결과}

\section{1 기술통계량}

앞서 언급한 바와 같이 본 연구에서는 설문에 응답한 총 9,000개 중소기업 중에서 (1) 식별번호가 누락된 기업(73개), (2) 주거래금융기관이 비은행금융기관인 기업(119개)을 제외한 8,808개 중소기업을 분석대상으로 한다. 이 중에서 대출수요가 없다고 응답한 기업은 5,233 개 기업이며, 이들도 분석에서 제외되었다. 따라서 본 연구에서는 대출수요가 있다고 응답한 3,575 개 중소 기업만 분석에 사용하였다. 대출수요가 있다고 응답한 기업 중 3,109 개 기업은 대출을 신청 하였으며, 466개 기업은 대출신청을 하지 않았다. 대출을 신청한 기업 중에서 2,811개 기업은 대출이 승인되었으며, 298개 기업은 대출이 거절되었다. 
〈표 3〉 분석대상 표본기업 수

\begin{tabular}{ccccc}
\hline \multicolumn{2}{c}{ 대출신청 } & 여부 $(\mathrm{N}=3,575)$ & & \multicolumn{2}{c}{ 대출승인 여부 $(\mathrm{N}=3,109)$} \\
\cline { 1 - 2 } \cline { 4 - 5 } \cline { 4 - 5 } 미신청 & 신청 & & 승인 & 거절 \\
\hline 466 & 3,109 & & 2,811 & 298 \\
\hline
\end{tabular}

<표 4>는 대출낙담, 대출신청, 대출승인, 대출거절 기업 사이의 평균차이를 분석한 결과이다. 먼저 대출낙담 기업과 대출신청 기업을 비교한다. 여기서 대출낙담 기업(discouraged firms)이란 대출이 거절될 것으로 짐작하여 대출신청을 스스로 포기한 기업을 말한다. 대출특성을 살펴보면,

〈표 4〉 대출낙담, 대출신청, 대출승인, 대출거절 기업에 대한 평균차이 검정 자료는 2016년, 2017년 『중소기업금융실태조사』에서 추가대출이 필요하다고 응답한 3,575개 기업으로 구성되어 있다. 두 표본그룹 사이의 평균차이를 검정하기 위하여 비모수적 접근방법인 윌콕슨 순위합 검정을 사용하였다. 각 변수들의 정의는 <표 $2>$ 에 요약되어 있다. ${ }^{* * *},{ }^{* *}$, *는 각각 $1 \%, 5 \%, 10 \%$ 수준에서 통계적으로 유의함을 나타낸다.

\begin{tabular}{|c|c|c|c|c|c|c|}
\hline & \multirow{2}{*}{$\begin{array}{c}\begin{array}{c}\text { 대출낙담 } \\
(\mathrm{N}=466)\end{array} \\
(1)\end{array}$} & \multirow{2}{*}{$\begin{array}{c}\begin{array}{c}\text { 대출신청 } \\
(\mathrm{N}=3,109)\end{array} \\
(2)\end{array}$} & \multirow{2}{*}{$\begin{array}{c}\begin{array}{c}\text { 대출거절 } \\
(\mathrm{N}=298)\end{array} \\
(3)\end{array}$} & \multirow{2}{*}{$\begin{array}{c}\begin{array}{c}\text { 대출승인 } \\
(\mathrm{N}=2,811)\end{array} \\
(4)\end{array}$} & \multicolumn{2}{|c|}{ Wilcoxon Z } \\
\hline & & & & & $(1)-(2)$ & $(3)-(4)$ \\
\hline \multicolumn{7}{|l|}{ Relationship Lending } \\
\hline Number of banks & 1.589 & 1.971 & 2.356 & 1.934 & $-6.565^{* * *}$ & $4.959^{* * *}$ \\
\hline Main bank's debt share & 0.794 & 0.734 & 0.734 & 0.784 & $1.845^{*}$ & $-2.939^{* * *}$ \\
\hline Relationship duration & 9.393 & 10.099 & 8.752 & 10.234 & $-1.419^{*}$ & $-3.314^{* * *}$ \\
\hline \multicolumn{7}{|l|}{ Loan Characteristics } \\
\hline Bank Loan & 0.693 & 0.874 & 0.839 & 0.877 & $-10.175^{* * *}$ & $-1.894^{*}$ \\
\hline Nonbank Loan & 0.536 & 0.620 & 0.648 & 0.617 & $-3.437^{* * *}$ & 1.041 \\
\hline Policy Fund Loan & 0.034 & 0.227 & 0.205 & 0.230 & $-9.675^{* * *}$ & -0.983 \\
\hline \multicolumn{7}{|l|}{ Firm Characteristics } \\
\hline InSale & 7.276 & 8.334 & 7.981 & 8.372 & $-12.625^{* * *}$ & $-3.594^{* * *}$ \\
\hline Tangible asset & 0.347 & 0.367 & 0.352 & 0.369 & -1.538 & -1.288 \\
\hline Leverage & 0.683 & 0.627 & 0.696 & 0.620 & $3.235^{* * *}$ & $4.956^{* * *}$ \\
\hline lnFage & 2.254 & 2.370 & 2.271 & 2.380 & $-2.871^{* * *}$ & $-1.813^{*}$ \\
\hline Sales growth & -0.168 & -0.021 & 0.014 & -0.024 & $-3.354^{* * *}$ & 1.117 \\
\hline $\mathrm{ROA}$ & 0.041 & 0.039 & 0.029 & 0.040 & -0.556 & -1.259 \\
\hline Cash & 0.070 & 0.073 & 0.040 & 0.077 & $-1.796^{*}$ & $-6.331^{\text {*** }}$ \\
\hline $\mathrm{R} \& \mathrm{D}$ & 0.003 & 0.008 & 0.005 & 0.009 & -5.725 & -2.703 \\
\hline Low Risk & 0.059 & 0.206 & 0.043 & 0.224 & $-7.641^{* * *}$ & $-7.399^{* * *}$ \\
\hline \multicolumn{7}{|l|}{ CEO Characteristics } \\
\hline Y30 & 0.051 & 0.050 & 0.066 & 0.048 & 0.083 & 1.349 \\
\hline Y60 & 0.288 & 0.286 & 0.218 & 0.294 & 0.080 & $-2.776^{* * *}$ \\
\hline Female & 0.172 & 0.121 & 0.155 & 0.118 & $3.057^{* * *}$ & $1.901^{*}$ \\
\hline \multicolumn{7}{|c|}{ Credit Market Characteristics } \\
\hline HHI & 0.199 & 0.187 & 0.190 & 0.187 & $1.883^{*}$ & -0.049 \\
\hline MSA & 0.517 & 0.517 & 0.601 & 0.508 & -0.003 & 3.064 \\
\hline $\operatorname{lnGDP}$ & 10.292 & 10.300 & 10.325 & 10.297 & -0.472 & 1.564 \\
\hline
\end{tabular}


The Impact of Relationship Lending on Bank Loan Process for Korean SMEs

대출낙담 기업은 대출신청 기업에 비해 기존 은행 대출, 비은행금융기관대출, 정책자금대출을 보유한 비중이 작았다. 기업특성에서는 대출낙담 기업이 대출신청 기업에 비해 기업규모 (lnSale)가 작고, 업력(lnFage)이 짧으며, 레버리지(Leverage)가 높고, 신용위험이 높은 특성을 보인다. $\mathrm{CEO}$ 특성에서는 대출낙담 기업이 대출신청 기업에 비해 여성 $\mathrm{CEO}$ 의 비중이 높았다.21) 관계금융의 특성에서는 대출낙담 기업이 대출신청 기업에 비해 주거래은행 거래기간이 상대적 으로 짧지만, 거래은행 수가 적고, 주거래은행의 대출비중은 상대적으로 높게 나타났다. 결과적으로 대출낙담 기업은 대출신청 기업에 비해 대출경험은 작고, 주거래은행 의존도가 높으며, 신용도가 좋지 않아 타은행으로 거래를 확장하기 어렵다. 따라서 이들 기업은 주거래은행 에서 추가대출 가능성이 낮다고 스스로 판단하여 대출신청을 포기하는 자기할당(self-rationing)의 특성을 보일 수 있다.

다음으로 대출거절 기업과 대출승인 기업을 비교해보면, 대출거절 기업은 대출승인 기업에 비해 기업규모(lnSale)가 작고, 업력(lnFage)이 짧으며, 현금(Cash)이 적었다. 또한 레버리지 (Leverage)가 높으며, 신용위험이 높은 특성을 보인다. 관계금융의 특성에서는 대출거절 기업이 대출승인 기업에 비해 거래은행 수가 많고, 주거래은행의 대출비중은 낮고, 주거래은행 거래기간도 짧게 나타나 주거래은행과의 관계의 강도가 상대적으로 낮게 나타났다.

이상의 결과에서 대출낙담 기업과 대출신청 기업 사이에, 대출승인 기업과 대출거절 기업 사이에 유의한 특성 차이가 있음을 발견하였다.

$<$ 표 5>는 산업별 대출승인/거절 분포를 나타낸다. 대출거절률(rejection rate)은 대출신청 기업 수 대비 대출거절 기업 수 비중이다. 산업전체 평균 대출거절률은 $9.6 \%$ 이다. 대출거절률이 높은 업종으로는 교육 서비스업(24.4\%),22) 예술·스포츠·여가 관련 서비스업(17.5\%),23) 수리. 기타 개인 서비스업( $16.9 \%), 24)$ 운수업 $(14.4 \%)$, 건설업(12.8\%) 등이며, 대출거절률이 낮은 업종으로는 전문·과학·기술 서비스업(5.0\%), 보건·사회복지 서비스업(7.1\%), 출판·영상·통신 (7.8\%), 제조업(8.6\%) 등으로 나타났다. 즉 소상공인·자영업 관련 업종은 대출거절률이 높은 반면 전문기술, 제조업 등은 낮게 나타났다.

<표 6>은 관계금융 변수 간 상관관계를 보여주고 있다. 관계금융 변수 중에서 대출거래은행 수(Number of banks)와 주거래은행 대출비중(Main bank's debt share) 사이에 높은 상관관계를 보이고 있어, 이들 세 변수들을 하나씩 따로 분석하였다. 나머지 변수들의 상관계수는 크게 높지 않아 지면관계상 생략하였다.

21) 이러한 결과는 우리나라 중소기업 대출시장에서 여성 $\mathrm{CEO}$ 에 대한 차별적 진입장벽이 존재한다기 보다는 여성 $\mathrm{CEO}$ 가 실질 경영자가 아닐 가능성에 기인한다. 우리나라 대출시장에서 남성 $\mathrm{CEO}$ 가 부도, 대출원리금 미상환, 신용불량, 세금체납 등으로 폐업할 경우 배우자인 여성을 대표이사로 하여 재창업하고, 실제 경영은 남성이 계속하는 경우가 종종 있다. 이런 기업들은 재창업 이후 대출신청 시 금융기관에 의해 이러한 사실에 대해 합리적 의심을 받게 되고, 일반기업에 비해 대출이 거절될 가능성이 높다. 따라서 이를 짐작한 기업들은 대출신청을 포기하는 대출낙담자로 전락할 수 있다.

22) 주요 업종으로는 보습학원, 온라인 교육학원, 미술학원, 음악학원, 축구교실, 태권도학원 등

23) 주요 업종으로는 공연시설 운영업, 독서실, 동식물 운영업, 골프장, 볼링장, 당구장 등

24) 주요 업종으로는 미용업, 세탁소, 장의업, 예식장업, 결혼상담업, 개인 간병인 등 
〈표 5〉 산업별 대출승인 및 대출거절의 표본분포

아래 표는 산업별 대출낙담, 대출신청, 대출거절, 대출승인의 표본분포를 보여준다. 자료는 2016년, 2017년 『중소기업금융실태조사』에서 추가대출이 필요하다고 응답한 3,575 개 기업으로 구성되어 있다.

\begin{tabular}{|c|c|c|c|c|c|}
\hline & $\begin{array}{c}\text { 대출낙담 } \\
\text { (개) }\end{array}$ & $\begin{array}{c}\text { 대출신청 } \\
\text { (개) }\end{array}$ & $\begin{array}{c}\text { 대출거절 } \\
\text { (개) }\end{array}$ & $\begin{array}{c}\text { 대출승인 } \\
\text { (개) }\end{array}$ & $\begin{array}{c}\text { 대출거절률 } \\
(\%)\end{array}$ \\
\hline & (1) & (2) & (3) & (4) & $(3) /(2)$ \\
\hline 제조업 & 244 & 1,786 & 153 & 1,633 & 8.6 \\
\hline 건설업 & 40 & 180 & 23 & 157 & 12.8 \\
\hline 도소매업 & 34 & 208 & 19 & 189 & 9.1 \\
\hline 운수업 & 23 & 139 & 20 & 119 & 14.4 \\
\hline 숙박 및 음식점업 & 10 & 98 & 9 & 89 & 9.2 \\
\hline 출판·영상·통신 & 32 & 193 & 15 & 178 & 7.8 \\
\hline 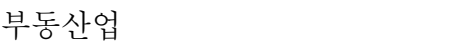 & 2 & 42 & 5 & 37 & 11.9 \\
\hline 전문·과학·기술 서비스업 & 16 & 161 & 8 & 153 & 5.0 \\
\hline 사업시설관리·사업지원 서비스업 & 16 & 59 & 7 & 52 & 11.9 \\
\hline 교육 서비스업 & 10 & 41 & 10 & 31 & 24.4 \\
\hline 보건·사회복지 서비스업 & 3 & 56 & 4 & 52 & 7.1 \\
\hline 예술·스포츠·여가 관련 서비스업 & 15 & 63 & 11 & 52 & 17.5 \\
\hline 수리·기타 개인 서비스업 & 21 & 83 & 14 & 69 & 16.9 \\
\hline 합계 & 466 & 3,109 & 298 & 2,811 & 9.6 \\
\hline
\end{tabular}

〈표 6〉관계금융 변수 간 상관관계

아래 표는 주요 관심변수인 관계금융 변수 간 상관관계를 나타낸다. Number of banks는 대출거래은행 수, Main bank's debt share는 주거래은행 대출비중, Relationship duration는 주거래은행 거래기간이다. ( )안은 $\mathrm{p}$-값을 나타낸다.

\begin{tabular}{lcc}
\hline & Number of banks & Main bank's debt share \\
\hline Main bank's debt share & $-0.429(0.000)$ & 1 \\
Relationship duration & $0.061(0.000)$ & $0.009(0.504)$ \\
\hline
\end{tabular}

\subsection{2단계 선택 추정: 대출신청 및 대출승인}

본 연구에서는 표본선택편의를 고려한 이변량 프로빗 모형을 이용하여 신용제약 확률을 추정한다. 분석결과는 <표 7>에 나타나 있다. 독립변수는 관계금융 변수, 대출특성 변수, 기업특성 변수, $\mathrm{CEO}$ 특성 변수, 대출시장 변수, 산업특성 변수를 포함하였다. Heckman의 2단계 추정절차에서 연구개발집약도(R\&D)를 도구변수로 하여 분석하였다.25)

25) 도구변수의 최적조건은 선택방정식의 종속변수와는 밀접한 관계가 있으면서, 결과방정식의 종속 변수와는 관계가 적은 변수이어야 한다. 연구개발집약도(R\&D)는 선택방정식의 종속변수(Applied) 와는 $0.072(\mathrm{p}-$ Value $<0.01)$ 의 상관계수 값을 가지지만, 결과방정식의 종속변수(Approved)와는 0.030 ( $\mathrm{p}$-Value=0.102)의 상관계수 값을 가지고, 유의하지도 않아 이러한 조건을 만족한다고 할 수 있다. 
The Impact of Relationship Lending on Bank Loan Process for Korean SMEs

\subsection{1 대출신청: 관계금융의 역할}

은행-기업 관계를 나타내는 변수인 대출거래은행 수(Number of banks), 주거래은행 대출비중(Main bank's debt share), 주거래은행 거래기간(Relationship duration)은 종속변수인 대출신청(Applied)과 모두 유의한 결과를 보이지 않았다. 이는 Cenni et al.(2015)과 동일한 결과로서, 대출신청의 경우 관계의 강도가 아니라 해당 기업의 자금수요에 기인한 결과라고 생각된다.

대출특성 변수에서는 기존 은행대출, 비은행금융기관대출, 정책자금대출을 보유하고 있는 기업들이 이들 대출을 보유하고 있지 않은 기업들에 비해 신규 대출신청 가능성이 높았다.

기업특성 변수에서는 기업규모( $\operatorname{lnSale})$ 가 클수록, 업력(lnFage)이 짧고 수익성(ROA)이 낮은 기업들일수록 신규 대출신청 가능성이 높게 나타났다. 또한 성장성(Sales growth)이 높고, 연구개발 집약도 $(\mathrm{R} \& \mathrm{D})$ 가 높을수록, 그리고 신용위험과 레버리지가 낮은 기업들일수록 신규대출을 신청할 가능성이 높게 나타났다. 이처럼 추가 대출을 신청한 기업들은 신용위험은 낮지만 업력이 짧고 수익성이 좋지 않아 자금사정이 나쁜 기업들, 규모가 크고 성장성이 높아 더 많은 자금이 필요한 기업들로 추정된다.

대출시장 변수 중에서는 해당 지역의 1 인당 지역내총생산 $(\mathrm{lnGDP})$ 이 클수록 대출신청 가능성이 더 높게 나타났다. 경제력이 좋은 지역일수록 자금수요가 더 크게 나타난 결과로 보인다. $\mathrm{CEO}$ 특성 변수에서는 유의미한 결과를 보이지 않았다.

요약하면 추가 대출신청에 대한 가능성은 기업의 자금수요에 기인하며, 은행-기업 관계나 $\mathrm{CEO}$ 의 특성과는 관련성이 없었다.

\subsection{2 대출승인: 관계금융의 역할}

관계금융 변수들은 종속변수인 대출승인(Approved)과 유의한 관계를 보였다. 먼저 대출거래 은행 수(Number of banks)는 1개 증가할수록 대출승인 확률은 약 $9.4 \%$ 씩 낮아졌다. 대출거래 은행 수가 많아질수록 신용제약이 될 가능성이 높아진다는 것을 의미한다. 이러한 결과는 대출거래은행 수를 증가시키려는 기업들의 시도가 외부자금조달의 접근성을 제한하고 자금조달 비용을 증가시킨다는 선행연구들과 일치한다(Petersen and Rajan, 1994; Berger and Udell, 1995; Cole, 1998; Degryse and van Cayseele, 2000). 은행의 입장에서 다수은행 거래관계는 단일은행 거래관계에 비해 재융자 과정(refinancing process)이 더 경쟁적이고 수익성은 더 낮아지면서 추가적인 신용확장을 어렵게 하는 요인이 된다.

주거래은행 대출비중(Main bank's debt share)은 대출승인(Approved)과 유의한 양의 관계를 보였다. 주거래은행 대출비중이 높은 기업일수록 신규대출이 승인될 가능성이 높아지며, 이는 곧 신용제약이 완화됨을 의미한다. 기업이 현재 이용하고 있는 주거래은행(최다대출은행)에서 신규대출을 신청하게 되면, 불확실성이 높은 차입자를 식별하고 감시하는데 소요되는 은행의 정보 수집비용은 낮아지기 때문에 이들 기업에 대한 은행의 대출승인 가능성은 높아진다고 할 수 있다. 


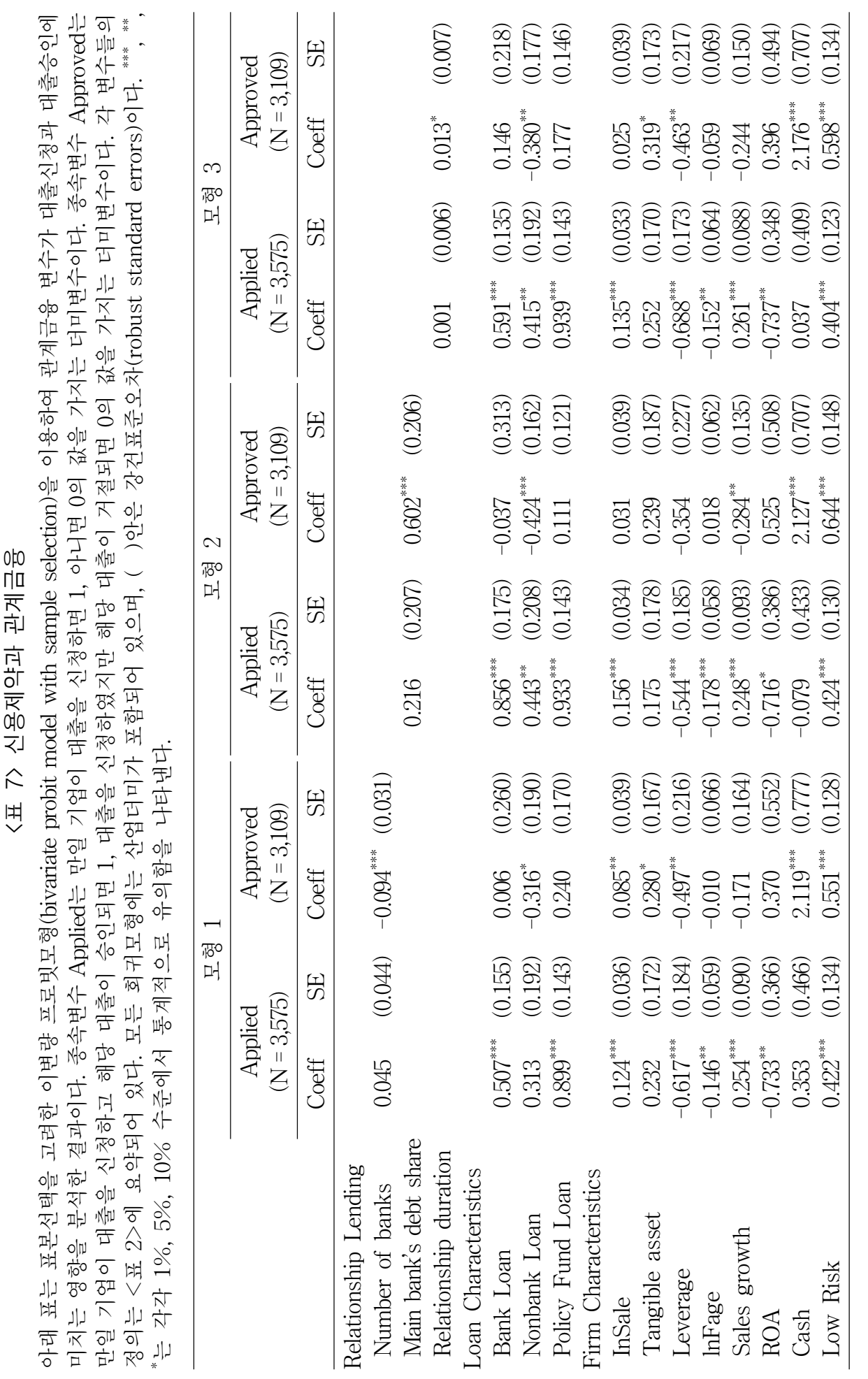


The Impact of Relationship Lending on Bank Loan Process for Korean SMEs

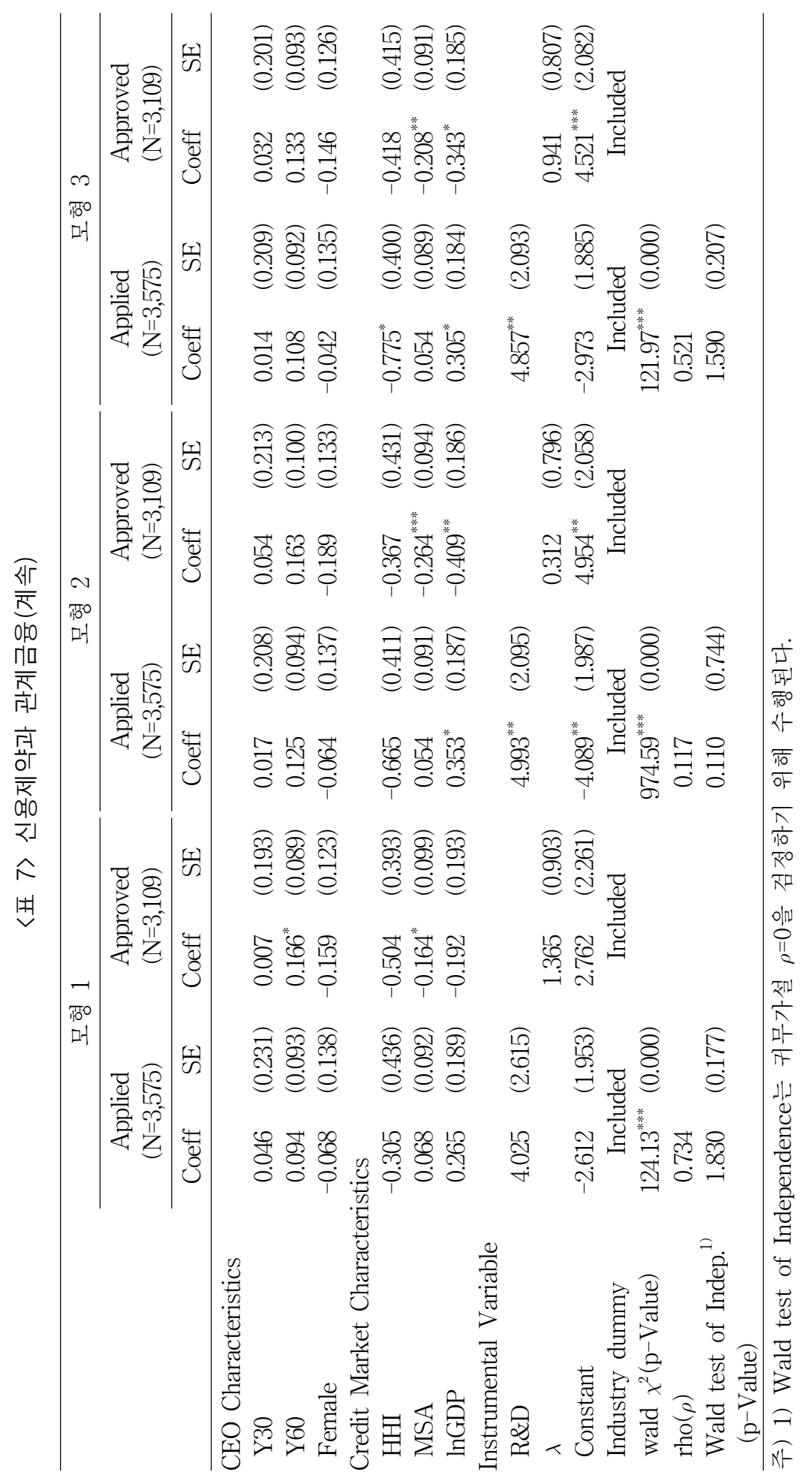


한국증권학회지 제50권 5호 (2021)

주거래은행 거래기간(Relationship duration)도 대출승인(Approved)과 양의 관계를 보였다. 은행은 오랜 기간에 걸쳐 기업과 일련의 반복적인 거래를 통해 기업과 밀접한 거래관계를 형성하게 된다. 그 과정에서 은행은 효율적으로 더 많은 정보를 수집하게 되고, 정보수집 비용은 낮아진다 (Boot and Thakor, 1994; Petersen and Rajan, 1994). 또한 은행에 의해 축적된 정보자본은 시간에 따라 그 가치가 높아진다. 따라서 이러한 실증 결과는 은행이 절감된 정보수집 비용에 대한 보상으로 신뢰할만한 고객에게 더 나은 계약조건을 수여한 것으로 해석할 수 있다. 또한 은행은 중소기업과 오랜 경험을 가질 때 해당 기업에 대한 대출을 덜 위험한 것으로 간주하는 경향이 있음을 유추해 볼 수 있다.

결론적으로 은행-기업 관계가 강할수록 대출이 승인될 가능성이 높게 나타났다. 이는 은행-기업 관계가 밀접할수록 신용제약이 완화되는 효과가 있음을 의미한다. 은행-기업 사이 강한 거래관계는 주거래은행에게 가치있는 정보지대(information rent)를 제공하고, 이는 중소기업이 자금이 필요할 때 은행으로부터 신용공여를 확보할 수 있는 가능성을 높인다고 할 수 있다(Cenni et al., 2015).

통제변수들의 효과를 살펴보면, 비은행금융기관대출을 보유한 기업들은 대출승인 가능성이 낮게 나타났다. 비은행금융기관과 거래하는 기업들은 은행만 거래하는 기업들에 비래 상대적으로 신용도가 낮을 것이기 때문에 대출이 거절될 가능성이 높다. 현금흐름(Cash)이 좋은 기업일수록 대출승인 가능성이 높게 나타났다. 은행이 대출승인 결정에서 기업의 원리금 상환능력을 중요시 하는데 현금흐름은 기업의 원리금 상환능력을 측정할 수 있는 좋은 지표이기 때문으로 풀이된다. 저위험등급(Low Risk)은 대출승인과 유의한 양의 관계를, 레버리지(Leverage) 변수와는 유의한 음의 관계를 보였다. 신용위험과 레버리지가 낮은 기업일수록 대출승인 확률이 높게 나타난 것은 당연한 결과라고 생각된다.

그런데 기업규모(nSale)는 모형 1에서만 양의 관계를 보이고, 모형 2, 3에서는 유의한 관계를 보이지 않았다. 기업의 담보능력을 측정할 수 있는 유형자산(Tangible asset)은 모형 1, 3에서 약한 양의 관계를 보였다. 수익성(ROA)과 기업업력(lnFage)은 유의한 관계를 보이지 않았다. 이처럼 은행의 대출승인 의사결정에 강한 영향을 미칠 것으로 기대한 요인들(정보투명성, 담보능력, 수익성, 평판자본 등)의 영향력이 기대와는 달리 약하거나 혹은 없는 것으로 나타났다. 이는 은행의 대출승인 의사결정이 기업의 한 면만 보는 것이 아니라 전반적인 신용도26)를 측정하는 것이기 때문에 이들 각각의 변수와는 유의한 관계가 약하게 나타난 것으로 추측된다.

기타 요인으로는 모형 1 에서 $\mathrm{CEO}$ 연령이 60 세 이상인 기업만 대출승인과 약한 양의 관계를 보인 것을 제외하고는 $\mathrm{CEO}$ 연령과 성별은 대출승인과 유의한 관계가 없었다. 대출시장 집중도 (HHI)와 대출승인 간에는 유의한 관계를 보이지 않았다. 선행연구에 따르면 대출집중도가 증가 할수록 대출공급이 제한(Boot and Thakor, 2000)된다거나 반대로 독점적 시장지배력은 대출 공급을 증가(Petersen and Rajan, 1995)시킨다는 보고가 있으나, 국내 대출시장은 어느 경우에도 해당되지 않았다. 대출을 신청한 중소기업 중 수도권에 소재하는(MSA) 중소기업은 비수도권

26) Green(2005)은 “대출은 과학이 아니라 예술이다(Lending is an art, not a science)"라고 하면서, 중소기업이 대출신청 시 은행이 중요하게 보는 5C(Capacity, Capital, Collateral, Credit, Character)를 고려하라고 하였다. 
The Impact of Relationship Lending on Bank Loan Process for Korean SMEs

소재 중소기업에 비해 대출승인 확률이 낮았다. 또한 해당 지역의 1 인당 지역내총생산(nGDP)이 클수록 대출 승인확률이 낮게 나타났다. 수도권과 경제력이 좋은 지역이 그렇지 않은 지역에 비해 신용제약 확률이 높게 나타난 것은 다소 의외의 결과이다.

한편 자기선택 모수인 $\lambda$ 의 계수 추정치들은 양의 부호를 가진다. 이는 대출을 신청할 것으로 기대되는 중소기업 차주는 대출을 신청하지 않을 것으로 기대되는 중소기업 차주에 비해 대출승인 확률이 더 높다고 해석될 수 있다. 그러나 $\lambda$ 의 계수가 유의하지 않았다. 이는 표본선택편의(sample selectin bias)가 존재하지 않으며27), 대출신청 여부와 대출승인 여부 사이에는 상호 독립적이라고 할 수 있다. 만일 대출낙담기업이 대출신청을 하게 된다면 동일한 조건의 대출신청 기업에 비해 대출이 거절될 가능성이 반드시 더 높다고 기대할 수는 없다. 실제로는 대출이 승인될 수 있음에도 불구하고 스스로 대출을 포기하는 기업이 발생한다는 것으로 해석할 수 있다. Kon and Storey(2013)에 따르면 국가경제에서 대출낙담의 규모는 은행의 식별오류28)와 대출신청비용29)의 수준에 달려있다. 우리나라 중소기업 대출시장에서 좋은 기업(good firms)이 대출신청을 포기할만큼 은행의 식별오류가 존재하거나, 대출접근이 어려울 수 있음을 시사한다.

\section{3 이중선택모형 : 대출금리 결정요인}

관계금융이 대출금리에 미치는 영향을 분석하기 위해 이중선택모형(double selectivity model)을 이용하였다. Heckman의 2 단계 추정절차에서는 연구개발집약도(R\&D)와 수도권 소재 여부 (MSA)를 도구변수로 하여 분석하였다. 이들 변수들은 대출신청과 대출승인 절차에 영향을 미칠 것으로 생각되지만 금리결정에는 영향이 적을 것으로 기대되어 결과방정식에만 제외하고 분석하였다. ${ }^{30)}$

이중선택모형의 추정절차는 다음과 같다. 먼저 2개의 선택방정식, 식 (1), (2)를 이용하여 $\gamma_{1}, \gamma_{2}, \rho$ 를 추정하고, 이를 이용하여 $\hat{\lambda}_{1}, \hat{\lambda}_{2}$ 를 계산한다. 이렇게 구한 $\hat{\lambda}_{1}, \hat{\lambda}_{2}$ 를 설명변수에 포함하는 결과방정식, 식 (4)를 추정한다. 분석결과는 <표 8>과 같다. 모형 $1,2,3$ 은 단순 OLS를 이용하여 분석한 결과이며, 모형 $4,5,6$ 은 이중선택모형을 이용하여 내재된 표본선택편의를 수정하여 분석한 결과이다.31)

27) 오차항들의 상관계수 $\mathrm{rho}(\rho)$ 는 모형 1 에서는 0.734 , 모형 2 에서는 0.117 , 모형 3 에서는 0.521 의 값을 가지지만 유의하지 않았다. 따라서 선택방정식의 오차항과 결과방정식의 오차항 간에는 상관관계가 없으며, 표본선택편의가 존재하지 않음을 나타낸다.

28) 식별오류란 좋은 기업(good firms)의 대출신청은 거절하고, 나쁜 기업(bad firms)의 대출신청은 승인하는 것을 말한다.

29) 대출신청비용이란 대출신청과 관련하여 소요되는 물질적, 심리적 비용을 말한다.

30) 도구변수의 최적조건은 선택방정식의 종속변수와는 밀접한 관계가 있으면서, 결과방정식의 종속 변수와는 관계가 적은 변수이어야 한다. 연구개발집약도(R\&D)는 선택방정식의 종속변수(Applied) 와는 $0.072(\mathrm{p}-$ Value $<0.01$ )의 상관계수 값을 가지지만, 결과방정식의 종속변수(Loan Rate)와는 -0.033 ( $\mathrm{p}-$ Value $=0.093$ )의 상관계수 값을 가진다. 수도권 소재 여부 $(\mathrm{MSA})$ 는 선택방정식의 종속변수 (Approved)와는 -0.059 ( $\mathrm{p}-$ Value $<0.01$ )의 상관계수 값을 가지지만, 결과방정식의 종속변수(Loan Rate)와는 $0.021(\mathrm{p}-$ Value $=0.290)$ 의 상관계수 값을 가진다.

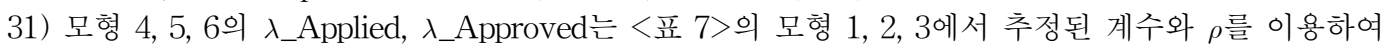
각각 계산된다. 
한국증권학회지 제50권 5호 (2021)

먼저 관계금융 변수의 효과를 살펴보면, 대출거래은행 수(Number of banks)는 대출금리(Loan Rate)와 유의한 양의 관계를 보였다. 이러한 결과는 다수은행과 거래관계를 유지하는 기업들이 단일은행 거래관계 기업들에 비해 자금조달에 있어 더 높은 대출금리에 직면할 수 있다는 선행연구 들과 일치한다(Petersen and Rajan, 1994; Berger and Udell, 1995). 모형 4에서 대출거래은행 수의 회귀계수가 0.064 로 나타났다. 이는 거래은행 수가 1 개 증가할 때 마다 대출금리가 $64 \mathrm{bp}$ 증가함을 의미한다. 주거래은행 대출비중(Main bank's debt share)은 대출금리(Loan rate)와 유의한 음의 관계를 보였다. 이는 차입을 하나의 은행에 집중하는 기업일수록 신규대출의 차입금리가 낮게 나타남을 의미한다. 모형 5에서 주거래은행 대출비중의 회귀계수가 -0.343 이므로 주거래은행 대출비중이 $10 \% \mathrm{p}$ 씩 증가하면 대출금리는 $3.43 \mathrm{bp} 32$ 씩 낮아진다. 기업이 주거래은행(최다대출은행) 에서 신규대출을 받게 되면, 해당 은행은 경쟁은행에 비해 독점적으로 정보확보가 용이하고, 다수은행 거래관계 기업을 상대했을 때보다 거래비용이 절감된다. 그래서 기업의 차입집중으로부터 은행은 규모의 경제 효과를 얻게 되고, 이는 대출금리 인하로 나타날 수 있다(Petersen, 2004). 한편 모형 3과 6에서 주거래은행 거래기간과 대출금리 사이에는 어떠한 관련성도 발견할 수 없었다. 이는 대출금리와 주거래은행 거래기간 사이에 음의 관계를 가진다고 한 Berger and Udell(1995)과 다른 결과이다. 반면 Cole(1998)은 대출금리 결정 단계에서 은행-기업 관계의 역할은 대출승인 단계에서의 은행-기업 관계의 역할과 다를 수 있다고 하면서 거래기간은 대출금리 결정 단계에서 중요하지 않다고 주장하였다. Petersen and Rajan(1994)은 대출금리와 주거래은행 거래기간 사이에는 관련성이 없다고 주장하였다. 그들은 대출금리 결정에서 단순한 거래기간의 길이보다는 오히려 거래관계의 깊이가 더 중요 하다고 하면서, 기업이 은행과 다양한 금융상품을 거래할 경우 은행은 차입자에 대한 정보의 정확성을 높이고, 정보수집비용을 절감할 수 있기 때문에 기업에게 대출금리 인하를 통해 이익의 일부를 공유한다고 하였다.33)

결론적으로 대출거래은행 수가 적을수록, 주거래은행 대출비중이 높을수록 대출금리가 낮게 나타났으며, 이는 한국 중소기업 대출시장에서 관계금융의 편익효과가 존재함을 의미한다.

통제변수들의 효과를 살펴보면, 먼저 담보를 제공하거나 정책자금대출을 보유한 기업은 대출금리가 유의하게 낮았으며, 비은행금융기관대출을 보유한 기업은 유의하게 높았다.

기업규모(nSale)가 클수록, 유형자산(Tangible asset)이 많을수록, 현금보유(Cash)가 많을수록, 신용위험이 낮을수록(Low Risk) 대출금리가 유의하게 낮았다. 이는 은행이 대출금리 결정에서 정보비대칭성, 담보제공능력, 원리금상환능력, 신용위험 등을 반영한 결과로 보인다.

32) 대출금리는 \%단위로 입력하였으며, 대출비중은 비율 단위로 입력하였다. 따라서 대출비중이 10 단위 $(10 \% \mathrm{p})$ 씩 증가하면 대출금리는 $-0.0343 \% \mathrm{p}(=-0.343 / 10)$ 씩 감소한다.

33) 실제로 금융기관에서 대출금리 감면 시 가장 중요한 고려요소는 기여도이다. 기여도란 고객이 여러 가지 금융거래를 통해 은행에 가져다주는 이익을 말한다. 만약 고객의 기여도(혹은 잠재적 기여도)가 높을 경우 은행은 마진을 덜 보고서라도 고객과 거래하려는 유인이 커진다. 
The Impact of Relationship Lending on Bank Loan Process for Korean SMEs

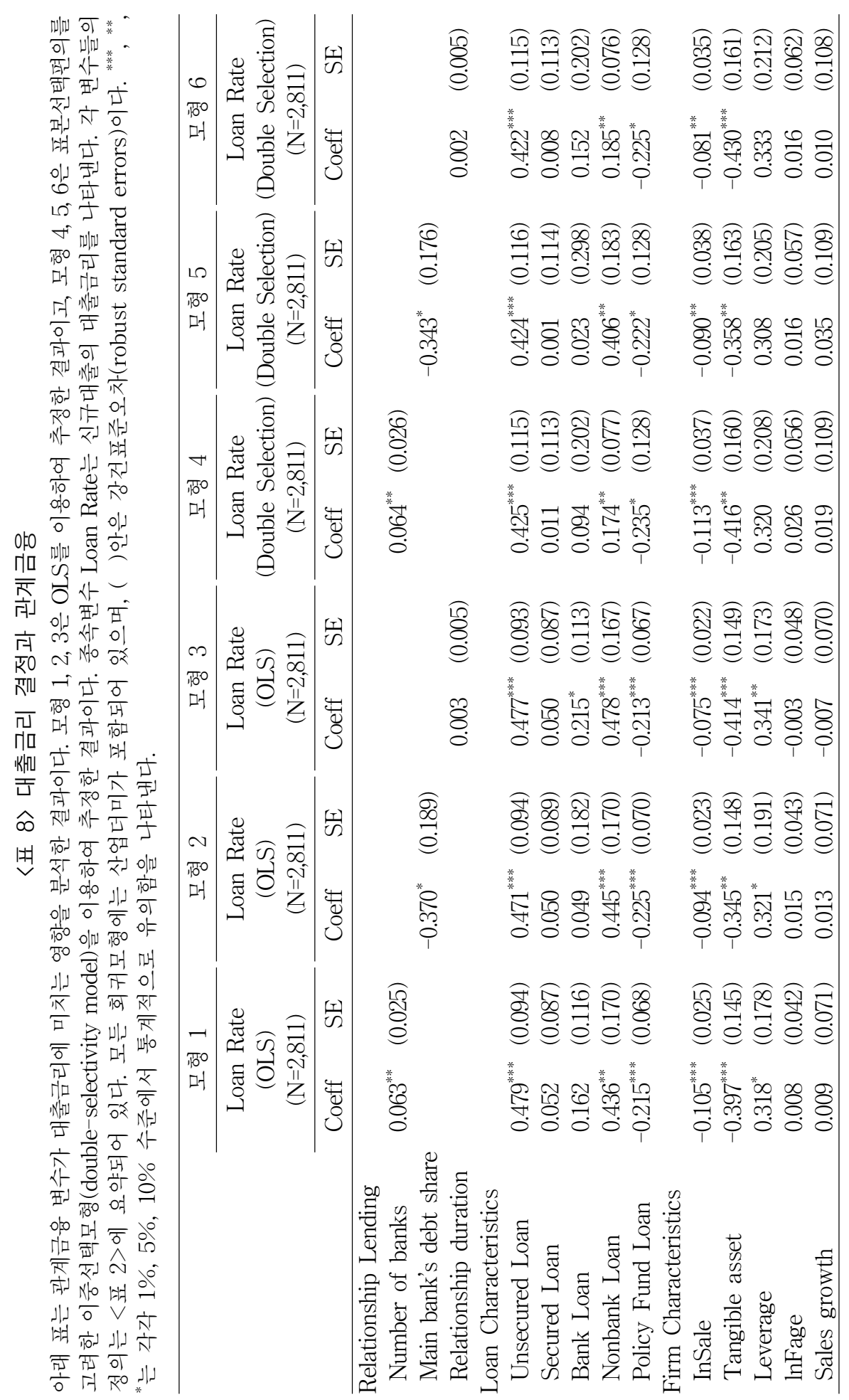




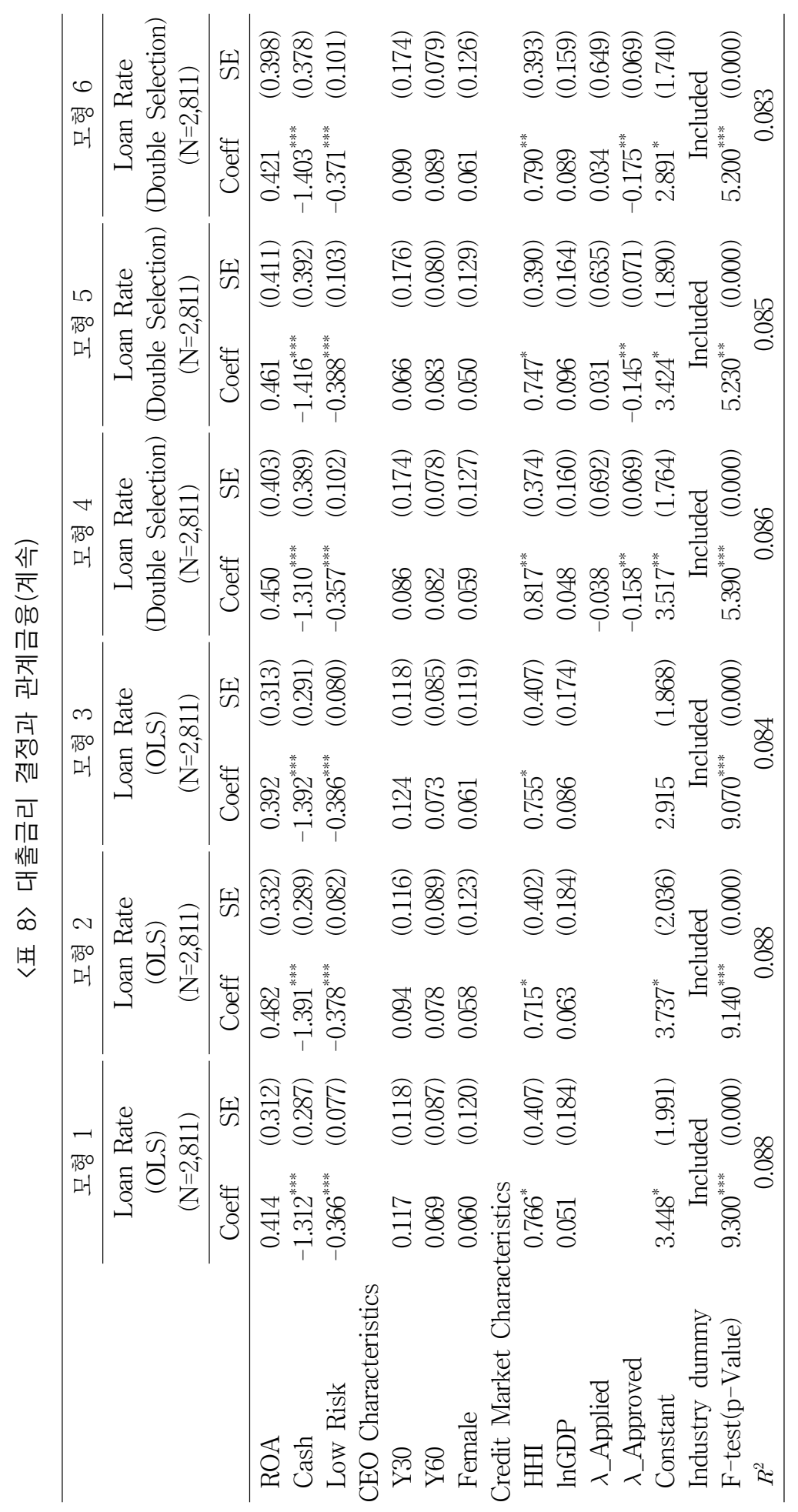


The Impact of Relationship Lending on Bank Loan Process for Korean SMEs

대출시장 변수 중에서 대출시장 집중도(HHI)는 대출금리와 양의 관계를 보였다. 즉 대출시장 집중도가 높을수록 대출금리가 높게 나타난 것이다. Bonini et al.(2016)에 따르면, 대출시장 집중도가 높을수록 차입자의 협상력이 약화되어 더 높은 금리를 부담하게 되고, 반대로 대출시장 집중도가 낮을 경우 은행들은 우량 신규고객 유치를 위해 낮은 금리를 제시할 가능성이 높다고 한다. 결국 대출시장에서 은행 간 경쟁이 높은 가격효율성을 이끌어낸 것이라고 할 수 있다.

한편 모형 4,5,6에서 자기선택 모수인 $\lambda$ 의 계수 추정치들( $\left.\lambda \_A p p l i e d, \lambda \_A p p r o v e d\right)$ 은 모두 음의 부호를 가진다. 이는 대출을 신청하는 기업의 특성들과 대출을 승인 받은 기업의 특성들이 대출금리와 음의 관계에 있음을 의미한다. 그러나 $\lambda \_A p p r o v e d$ 의 계수만 $5 \%$ 유의수준 하에서 유의한 결과를 보였으므로, 대출승인 방정식만 표본선택편의가 존재함을 의미한다. 즉 대출승인 받을 것으로 기대되는 중소기업 차주는 동일한 조건의 다른 중소기업에 비해 대출금리가 더

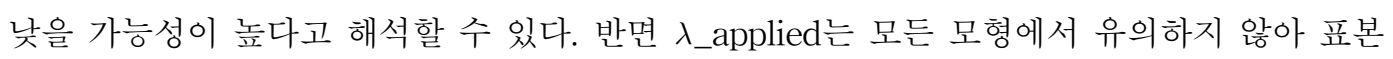
선택편의(sample selectin bias)가 존재하지 않음을 의미한다. 즉 대출신청 여부와 대출금리 수준 사이에는 상호 독립적이다.

\section{4 추가분석}

\subsection{1 대출규모 효과}

본 연구에서는 대출거래은행 수(Number of banks)가 적을수록 은행-기업 간 결속관계가 강하다고 가정하고 있는데, 이는 기존 은행대출액의 규모에 따라 다를 수 있다. 예를 들면 대출규모가 1 억 원인 기업 $\mathrm{A}$ 가 한 개의 은행과 거래하고 있고, 대출규모 10 억 원인 기업 $\mathrm{B}$ 가 5 억 원씩 2 개의 은행과 거래할 경우, 대출거래은행 수가 적은 기업 $\mathrm{A}$ 가 $\mathrm{B}$ 보다 반드시 은행과의 결속관계가 더 강하다고 말할 수 있는지는 논의의 여지가 있다. 주거래은행 비중 역시 대출규모에 따라 해석이 달라질 수 있다. 위의 예에서처럼 기업 A는 주거래은행 대출비중이 $100 \%$ (주거래은행 대출액 1 억원)이고 기업 $\mathrm{B}$ 는 주거래은행 대출비중이 $50 \%$ (주거래은행 대출액 5 억원)이지만 기업 $\mathrm{A}$ 가 $\mathrm{B}$ 보다 반드시 은행과의 결속관계가 더 강하다고 할 수는 없다. 따라서 대출규모에 따라 관계금융의 효과가 다르게 나타날 수 있으므로 대출규모를 통제할 필요가 있다.

<표 9> Panel A는 전체표본을 기존 은행대출액이 1억 원 이하인 기업과 기존 은행대출액이 1 억 원을 초과하는 기업으로 구분하여 분석한 결과이다. 분석방법은 <표 $7>,<$ 표 8>과 동일한 절차에 따라 실시하였으며, 관계금융 변수들은 세 변수를 각각 하나씩 따로 분석 후 하나의 표에 나타내었다. 관계금융 변수를 제외한 여타 설명변수는 지면관계상 생략하였다. 분석결과를 살펴보면, 기존 은행대출액 1억 원 초과 기업에서 관계금융 변수들은 대출승인(Approved)과 유의한 관계를 보인 반면, 기존 은행대출액 1 억 원 이하 기업에서는 유의한 결과를 보이지 않았다. 대출금리 결정 단계에서도 기존 은행대출액 1 억 원 초과 기업은 대출거래은행 수와 주거래은행 대출비중에서 유의한 관계를 보였으나, 기존 은행대출액 1 억 원 이하 기업은 유의한 관계를 보이지 않았다. 이러한 결과는 은행-기업 관계에서 대출규모 역시 중요하게 고려해야 할 요소임을 시사한다. 
〈표 9> 신용제약과 관계금융: 하위표본

아래 표는 표본을 기존 은행대출액 규모, $\mathrm{CEO}$ 성별, 대출시장 집중도로 나누어 신용제약과 관계금융의 관계를 분석한 결과이다. 분석방법은 <표 $7>$ 의 모형 $1,2,3,<$ 표 $8>$ 의 모형 $4,5,6$ 에서 사용된 것과 동일한 방법을 사용하였다. 종속변수 Applied는 만일 기업이 대출을 신청하면 1 , 아니면 0의 값을 가지는 더미변수이다. 종속변수 Approved는 만일 기업이 대출을 신청하고 해당 대출이 승인되면 1, 대출을 신청하였지만 해당 대출이 거절되면 0의 값을 가지는 더미변수이다. 종속변수 Loan Rate는 신규대출의 대출금리를 나타낸다. 관계금융 변수들은 세 변수를 각각 하나씩 따로 분석하였다. 관계금융 변수를 제외한 여타 설명변수는 지면관계상 생략하였다. 각 변수들의 정의는 <표 $2>$ 에 요약되어 있다. 모든 회귀모형에는 산업더미가 포함되어 있으며, ( )안은 강건표준오차(robust standard errors)이다. *** , ** *는 각각 1\%, $5 \%, 10 \%$ 수준에서 통계적으로 유의함을 나타낸다.

Panel A: 은행대출액 규모

\begin{tabular}{|c|c|c|c|c|c|c|}
\hline & \multicolumn{3}{|c|}{ 기존 은행대출액 1억원 이하 } & \multicolumn{3}{|c|}{ 기존 은행대출액 1억원 초과 } \\
\hline & Applied & Approved & Loan Rate & Applied & Approved & Loan Rate \\
\hline \multirow[t]{2}{*}{ Number of banks } & 0.069 & 0.015 & -0.060 & 0.020 & $-0.113^{* * *}$ & $0.071^{* * *}$ \\
\hline & (0.179) & $(0.161)$ & $(0.085)$ & $(0.043)$ & $(0.035)$ & $(0.027)$ \\
\hline \multirow[t]{2}{*}{ Main bank's debt share } & 1.017 & 0.474 & -0.335 & 0.253 & $0.612^{* * *}$ & $-0.392^{* *}$ \\
\hline & $(1.254)$ & $(0.812)$ & (1.153) & $(0.225)$ & $(0.220)$ & $(0.184)$ \\
\hline \multirow[t]{2}{*}{ Relationship duration } & 0.042 & -0.012 & -0.001 & -0.002 & $0.014^{*}$ & 0.003 \\
\hline & $(0.026)$ & $(0.037)$ & $(0.024)$ & $(0.006)$ & $(0.008)$ & $(0.005)$ \\
\hline \multicolumn{7}{|l|}{ Panel B: CEO 성별 } \\
\hline & \multicolumn{3}{|c|}{ 남성 } & \multicolumn{3}{|c|}{ 여성 } \\
\hline & Applied & Approved & Loan Rate & Applied & Approved & Loan Rate \\
\hline \multirow[t]{2}{*}{ Number of banks } & 0.027 & $-0.095^{* * *}$ & $0.069^{* *}$ & 0.183 & -0.103 & 0.086 \\
\hline & $(0.041)$ & $(0.029)$ & $(0.027)$ & $(0.178)$ & $(0.112)$ & $(0.160)$ \\
\hline \multirow[t]{2}{*}{ Main bank's debt share } & 0.258 & $0.695^{* * *}$ & $-0.491^{* * *}$ & -0.221 & -0.590 & 1.300 \\
\hline & $(0.222)$ & $(0.219)$ & $(0.185)$ & $(0.706)$ & $(0.713)$ & (0.998) \\
\hline \multirow[t]{2}{*}{ Relationship duration } & -0.002 & $0.013^{*}$ & 0.002 & 0.037 & -0.024 & 0.021 \\
\hline & $(0.007)$ & $(0.007)$ & $(0.005)$ & $(0.029)$ & $(0.042)$ & $(0.040)$ \\
\hline \multicolumn{7}{|l|}{ Panel C: 대출시장 집중도 } \\
\hline & \multicolumn{3}{|c|}{ 저집중시장 } & \multicolumn{3}{|c|}{ 고집중시장 } \\
\hline & Applied & Approved & Loan Rate & Applied & Approved & Loan Rate \\
\hline \multirow[t]{2}{*}{ Number of banks } & 0.066 & $-0.089^{* * *}$ & 0.041 & 0.034 & $-0.108^{*}$ & $0.113^{* *}$ \\
\hline & $(0.057)$ & $(0.033)$ & $(0.027)$ & $(0.054)$ & $(0.056)$ & $(0.049)$ \\
\hline \multirow[t]{2}{*}{ Main bank's debt share } & 0.457 & 0.438 & -0.025 & -0.032 & $0.556^{* *}$ & -0.425 \\
\hline & (0.376) & $(0.356)$ & (0.196) & (0.302) & $(0.241)$ & (0.318) \\
\hline \multirow[t]{2}{*}{ Relationship duration } & 0.010 & 0.012 & 0.003 & -0.008 & 0.006 & 0.005 \\
\hline & $(0.009)$ & $(0.010)$ & $(0.005)$ & $(0.009)$ & $(0.008)$ & $(0.010)$ \\
\hline
\end{tabular}

\subsubsection{CEO 성별 및 대출시장 집중도 효과}

Panel $\mathrm{B}$ 는 $\mathrm{CEO}$ 성별을 남성과 여성으로 구분하여 분석한 결과이다. 남성 $\mathrm{CEO}$ 에서 관계금융 변수들이 대출승인(Approved)과 유의한 관계를 보인 반면, 여성 CEO에서는 유의한 관계를 보이지 않았다. 대출금리 결정 단계에서도 남성 $\mathrm{CEO}$ 는 대출거래은행 수와 주거래은행 대출비중 
The Impact of Relationship Lending on Bank Loan Process for Korean SMEs

에서 유의한 관계를 보였으나, 여성 $\mathrm{CEO}$ 는 유의한 결과를 보이지 않았다. 결국 남성 $\mathrm{CEO}$ 는 대출승인과 대출금리 결정 단계에서 관계금융이 중요한 역할을 한 반면, 여성 $\mathrm{CEO}$ 는 그렇지 않았다.

Panel C는 대출시장 집중도를 저집중시장과 고집중시장으로 구분하여 분석한 결과이다. $\mathrm{HHI}$ 가 중앙값 미만이면 저집중시장, 중앙값 이상이면 고집중시장으로 구분하였다. 저집중시장 에서 대출거래은행 수만 대출승인과 유의한 음의 관계를 보인 반면, 고집중시장에서는 대출거래 은행 수와 주거래은행 대출비중이 대출승인과 유의한 관계를 보였다. 대출금리 결정 단계에서도 저집중시장은 유의한 결과를 보이지 않는 반면, 고집중시장은 대출거래은행 수에서 유의한 양의 관계를 보였다. 대출시장 집중도에서 고집중시장이 저집중시장에 비해 관계금융의 역할이 조금 더 크게 나타난 것을 확인할 수 있다. 이러한 결과는 관계금융과 대출시장 집중도 사이에는 양의 관계에 있다는 Petersen and Rajan(1995), Hwang and Lee(2014) 등의 연구결과와 일치한다.

\section{4 .3 통제변수들}

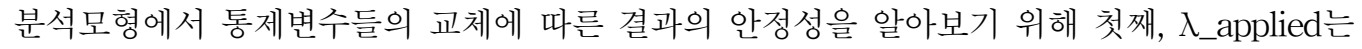
모든 모형에서 유의하지 않아 대출신청 여부에 관한 선택오류를 고려할 필요가 있는지에 대한 의문을 제기할 수 있다. 그래서 첫 번째 선택조건의 inverse Mill's ratio( $\left.\lambda \_a p p l i e d\right)$ 를 제거한 단일선택모형(single selection model)으로 하여 분석해 본 결과, 결과값에는 큰 차이가 없었다.

둘째, 기업규모의 대용변수로 매출액 대신 총자산이나 종업원 수로 대체하여도 분석결과에는 큰 차이가 없었다.

셋째, Cenni et al.(2015)의 연구에서처럼 관계금융 변수의 비선형 형태를 모형에 반영해 보았다. 차입집중에 따른 신용제약의 효과가 비선형일 가능성이 있을 수 있으므로 주거래은행 대출비중의 제곱항을 모형에 포함해 분석해 보았으나, 2차항의 계수가 유의하지 않았다. Berger and Udell(1995)에 따르면 대출기업에 대한 추가적인 정보의 기여도는 장기간이 경과하면 그 유용성이 떨어진다고 한다. 이에 따라 주거래은행 거래기간을 제곱근의 형태로 하여 분석하였으나 기존 결과와 큰 차이가 없었다.

\section{6. 결론}

중소기업의 경우 대기업에 비해 상대적으로 높은 정보의 비대칭성, 취약한 담보력, 과다한 거래비용, 높은 위험성 등 구조적인 문제로 인해 은행에서는 중소기업에 대한 대출을 기피하게 된다. 이에 따라 중소기업은 대출이 필요함에도 대출이 거절되는 신용제약이 나타나게 된다. 이와 같은 중소기업의 특성에도 불구하고 중소기업대출을 취급하는 은행들은 장기적 거래관계를 통해 신용정보의 생산이 가능한 관계금융(relationship lending) 행태로 정보의 비대칭성 문제를 해소하고, 나아가 기업 내부정보(private information)에 근거하여 대출승인 및 대출조건을 결정할 가능성이 있다. 따라서 관계금융이 중소기업의 대출접근성과 대출조건에 미치는 효과를 실증적으로 검증하는 것은 은행 중심의 자금조달체계 국가인 한국에서 중요한 문제이다. 
본 연구의 목적은 대출신청, 대출승인, 대출금리 결정의 3 단계 대출과정에서 관계금융의 역할을 알아보는데 있다. 그런데 이러한 3 단계의 대출과정은 내생적으로 결정되기 때문에 단절된 특정 단계의 추정모형은 모형의 오류로 인해 추정값이 실제와 차이를 보일 가능성이 있다. 또한 여러 단계의 대출과정에서 관계금융이 똑같이 중요한 역할을 하는지에 대해서도 의문의 여지가 있다. 본 연구에서는 이러한 사항들을 모두 고려하였으며, 나아가 그동안 선행연구에서 간과 되었던 대출낙담자를 모형에 포함하여 분석하였다. 여기서 대출낙담자란 대출수요는 있지만 은행에 의해 대출이 거절될 것으로 짐작하여 스스로 대출신청을 포기한 잠재적 차입자를 말한다.

실증분석을 위해 IBK경제연구소에서 전국에 소재한 중소기업을 대상으로 실시한 2016년, 2017년 『중소기업금융실태조사』에서 대출수요가 있다고 응답한 3,575개 기업의 설문자료에다 각 응답기업의 해당 연도 재무자료를 대응시켜 분석하였다.

분석결과를 요약하면 다음과 같다. 첫째, 관계금융 변수는 대출신청과 유의한 결과를 보이지 않았다. 이는 중소기업들이 추가 대출을 신청할 가능성은 기업의 자금수요에 기인하며, 은행-기업 관계와는 관련성이 없음을 의미한다. 통제변수들의 효과를 살펴보면, 기존대출(은행·비은행. 정책자금대출)을 보유한 기업일수록 신규대출을 신청할 가능성이 높았다. 또한 기업규모가 크고, 업력이 짧은 기업일수록, 수익성이 낮고, 성장성이 높은 기업일수록, 신용위험과 레버리지가 낮은 기업일수록 신규대출을 신청할 가능성이 높았다.

둘째, 은행-기업 관계가 강할수록 대출이 승인될 가능성이 높게 나타났다. 이는 은행-기업 관계가 밀접할수록 정보비대칭성 문제가 개선되어 신용제약이 완화되었음을 의미한다. 은행기업 사이의 강력한 거래관계는 주거래은행에게 가치있는 정보를 제공하고, 이는 자금이 필요한 중소기업에게 신용을 확보할 수 있는 가능성을 높인다고 할 수 있다. 한편 통제변수들의 효과를 살펴보면, 비은행금융기관대출을 보유한 기업들은 대출승인 가능성이 낮게 나타났으며, 기업의 현금흐름이 양호하고 레버리지와 신용위험이 낮은 기업일수록 대출승인 가능성이 높게 나타났다.

셋째, 관계금융이 대출금리에 미치는 영향을 분석한 결과, 대출거래은행 수가 적을수록, 대출이 하나의 은행에 집중되어 있을수록 대출금리가 인하되는 효과가 있었다. 이러한 결과들은 한국 중소기업 대출시장에서 관계금융의 편익효과가 작용하고 있음을 확인할 수 있는 증거이다. 한편 통제변수 중에서는 기업규모가 크고 현금흐름이 양호하며, 신용위험이 낮은 기업일수록 대출금리가 낮게 나타났다. 유형자산은 대출 담보로 활용될 가능성이 높기 때문에 대출금리와 유의한 음의 관계를 보였다. 대출시장의 집중도는 대출금리와 유의한 양의 관계를 보였는데, 이는 은행 간 경쟁이 높은 가격효율성을 이끌어 낸 결과로 해석된다.

결론적으로 국내 중소기업 대출시장의 수요측면에서는 관계금융의 영향이 나타나지 않았으나, 공급측면에서는 중소기업에게 개선된 금융접근성과 더 나은 대출조건을 제공하는 관계금융의 역할을 확인하였다. 이러한 사실은 자금조달이 어렵고 조달비용이 높은 중소기업에게 관계금융은 중요한 정책적 대안으로 활용될 수 있다는 시사점을 준다.

본 연구는 국내에서 자료 제약상 신용제약과 관계금융의 효과에 관한 논문이 많지 않은 현실에서 대출과정 단계별로 관계금융의 효과를 종합적으로 분석하였다는 점에서 그 의의가 있다. 일례로 
The Impact of Relationship Lending on Bank Loan Process for Korean SMEs

Lee and Hwang(2013)34)은 국내은행의 실제 대출계약 자료를 이용하여 은행-기업 결속관계가 대출금리에 미치는 영향을 규명하였는데, 본 연구는 여기에 더하여 대출신청과 대출승인 단계 에서도 관계금융의 역할이 작용하는지를 분석하였다는 점에서 그 공헌점이 있다고 하겠다. 이처럼 중소기업금융의 공급측면뿐만 아니라 수요측면도 함께 고려한 것은 중소기업금융 연구의 시야를 넓히는 새로운 시도이다.

본 연구는 관계금융의 형태나 거래관계의 밀착도 면에서 우리나라가 미국이나 유럽과는 차이가 날 수 있음에도 불구하고, 해외 선행연구를 국내에 그대로 적용함에 따라 한국적 관계금융의 특성을 제대로 파악할 수 없었다는 한계점을 가진다. 따라서 한국 중소기업 금융시장에서 은행-기업 관계의 밀접도를 나타내는 다양한 대용변수들을 분석에 포함하거나, 더 긴 시계열 설문자료를 활용한 추가 연구 등은 향후 연구과제로 남겨둔다.

34) Lee and Hwang(2013)은 은행-기업 관계의 밀접도를 거래기간, 거래상품수, 거래은행 수, 주거래은행 관계 여부, 단일은행 거래관계 여부로 측정하여 분석해 본 결과, 은행과의 거래기간이 길고 거래상품 수가 많을수록, 거래은행 수가 적을수록, 단일은행 거래관계일 경우 대출금리가 더 낮다고 보고하였다. 


\section{References}

Ang, J. S., 1991, Small Business Uniqueness and the Theory of Financial Management, Journal of Small Business Finance, Vol. 1, pp. 1-13.

Atzeni, G. E., and C. A. Piga, 2007, R\&D Investment, Credit Rationing and Sample Selection, Bulletin of Economic Research, Vol. 59, pp. 149-178.

Berger, A. N., and G. F. Udell, 1995, Relationship Lending and Lines of Credit in Small Firm Finance, Journal of Business, Vol. 68, pp. 351-381.

Berger, A. N., and G. F. Udell, 1998, The Economics of Small Business Finance: The Roles of Private Equity and Debt Markets in the Financial Growth Cycle, Journal of Banking and Finance, Vol. 22, pp. 613-673.

Bharath, S. T., S. Dahiya, A. Saunders, and A. Srinivasan, 2011, Lending Relationships and Loan Contract Terms, Review of Financial Studies, Vol. 24, pp. 1141-1203.

Binks, M. R., and C. T. Ennew, 1996, Growing Firms and the Credit Constraint, Small Business Economics, Vol. 8 (1), pp. 17-25.

Bonini, S., A. Dell'Acqua, M. Fungo, and V. Kysucky, 2016, Credit Market Concentration, Relationship Lending and the Cost of Debt, International Review of Financial Analysis, Vol. 45, pp. 172-179.

Boot, A., and A. Thakor, 1994, Moral Hazard and Secured Lending in an Infinitely Repeated Credit Market Game, International Economic Review, Vol. 35, pp. 899-920.

Boot, A., and A. Thakor, 2000, Can Relationship Banking Survive Competition?, Journal of Finance, Vol. 55, pp. 679-713.

Bougheas, S., P. Mizen, and Y. Yalcin, 2006, Access to External Finance: Theory and Evidence on the Impact of Monetary Policy and Firm-Specific Characteristics, Journal of Banking and Finance, Vol. 30 (1), pp. 199-227.

Cameron, A. C., and P. K. Trivedi, Microeconometrics: Methods and Applications, Cambridge University Press, New York, 2005.

Canton, E., I. Grilo, J. Monteagudo, and P. van der Zwan, 2013, Perceived Credit Constraints in the European Union, Small Business Economics, Vol. 41 (3), pp. 701-715.

CarboValverde, S., F. Rodriguez-Fernandez, and G. F Udell, 2009, Bank Market Power and SME Financing Constraints, Review of Finance, Vol. 13 (2), pp. 309-340.

Cavalluzzo, K., and L. Cavalluzzo, 1998, Market Structure and Discrimination: The Case of Small Businesses, Journal of Money, Credit and Banking, Vol. 30, pp. 771-792.

Cenni, S., S. Monferrà, V. Salotti, M. Sangiorgi, and G. Torluccio, 2015, Credit Rationing and Relationship Lending, Does Firm Size Matter?, Journal of Banking and Finance, 
The Impact of Relationship Lending on Bank Loan Process for Korean SMEs

Vol. 53, pp. 249-265.

Chakravarty, S., and T. Yilmazer, 2009, A Multistage Model of Loans and the Role of Relationships, Financial Management, Vol. 38 (4), pp. 781-816.

Cole, R. A., 1998, The Importance of Relationships to the Availability of Credit, Journal of Banking and Finance, Vol. 22, pp. 959-977.

Cole, R., and T. Sokolyk, 2016, Who Needs Credit and Who Gets Credit? Evidence from the Surveys of Small Business Finances, Journal of Financial Stability, Vol. 24, pp. 40-60.

Degryse, H., and P. Van Cayseele, 2000, Relationship Lending within a bank-based System: Evidence from European Small Business Data, Journal of Financial Intermediation, Vol. 9, pp. 90-109.

Degryse, H., and S. Ongena, 2001, Bank Relationships and Firm Profitability, Financial Management, Vol. 30 (1), pp. 9-34.

Degryse, H., and S. Ongena, 2005, Distance, Lending Relationships, and Competition, Journal of Finance, Vol. 60, pp. 231-266.

Degryse, H., and S. Ongena, 2007, The Impact of Competition on Bank Orientation, Journal of Financial Intermediation, Vol. 16, pp. 399-424.

Dewatripont, M., and E. Maskin, 1995, Credit and Efficiency in Centralized and Decentralized Economies, Review of Economic Studies, Vol. 62, pp. 541-555.

Diamond, D. W., 1991, Monitoring and Reputation: The Choice between Bank Loans and Directly Placed Debt, Journal of Political Economy, Vol. 99, pp. 689-721.

Elsas, R., 2005, Empirical Determinants of Relationship Lending, Journal of Financial Intermediation, Vol. 14, pp. 32-57.

Elyasiani, E., and L. G. Goldberg, 2004, Relationship Lending: A Survey of the Literature, Journal of Economics and Business, Vol. 56, pp. 315-330.

Evans, D. S., and B. Jovanovic, 1989, An Estimated Model of Entrepreneurial Choice under Liquidity Constraints, Journal of Political Economy, Vol. 97 (4), pp. 808-827.

Fisher, K. H., Acquisition of Information in Loan Markets and Bank Market Power: An Empirical Investigation, Working paper, Johann Wolfgang Goethe University, Frankfurt, 2000, http://dx.doi.org/10.2139/ssrn.240921.

Freel, M., 2007, Are Small Innovators Credit Rationed?, Small Business Economics, Vol. 28 (1), pp. 23-35.

Green, C. H., The SBA Loan Book, Get A Small Business Loan - even With Poor Credit, Weak Collateral, And No Experience, 2nd ed., Adams Media Corp., 2005.

Guiso, L., 1998, High-tech Firms and Credit Rationing, Journal of Economic Behaviour and 
한국증권학회지 제 50 권 5호 (2021)

Organization, Vol. 35, pp. 39-59.

Heckman, J. J., 1976, The Common Structure of Statistical Models of Truncation, Sample Selection and Limited Dependent Variables and a Simple Estimator for Such Models, Annals of Economic and Social Measurement, Vol. 5, pp. 475-492.

Heckman, J. J., 1979, Sample Selection Bias as a Specification Error, Econometrica, Vol. 47, pp. $153-161$.

Hernández-Cánovas, G., and P. Martìnez-Solano, 2010, Relationship Lending and SME Financing in the Continental European Bank-Based System, Small Business Economics, Vol. 34 (4), pp. 465-482.

Hwang, S. Y., and J. J. Lee, 2014, An Empirical Study on Creditor Concentration in Multiple Banking Relationships, Asian Review of Financial Research, Vol. 27 (4), pp. 669-708.

Kim, S., and J. Kim, 2007, Lines of Credit, Borrowing Costs, and Relationship Banking: Evidence from Korean Main Credit Banks, Korean Journal of Financial Studies, Vol. 36 (1), pp. 1-32.

Klein, R., and F. Vella, 2010, Estimating a Class of Triangular Simultaneous Equations Models without Exclusion Restrictions, Journal of Econometrics, Vol. 154 (2), pp. 154-164.

Kon, Y., and D. J. Storey, 2003, A Theory of Discouraged Borrowers, Small Business Economics, Vol. 21, pp. 37-49.

Lee, L.-F., 1983, Generalized Econometric Models with Selectivity, Econometrica, Vol. 51, pp. $507-512$.

Lee, S. W., 2009, The Effect of Firm Characteristics on Firm-Bank Relationships, Asian Review of Financial Research, Vol. 22 (2), pp. 37-70.

Lee, J. J., and S. Y. Hwang, 2013, An Empirical Study on the Effects of Bank-Firm Relationship on Small Firm Borrowings, Economic Analysis, Vol. 9 (1), pp. 77-105.

Muravyev, A., O. Talavera, and D. Schäfer, 2009, Entrepreneurs' Gender and Financial Constraints: Evidence from International Data, Journal of Comparative Economics, Vol. 37, pp. 270-286.

Ongena, S., and D. C. Smith, Bank Relationship: A Review, in P. Harker and S. A. Zenios(eds), The Performance of Financial Institutions(pp. 221-258), Cambridge University Press, Cambridge, 2000.

Petersen, M. A., Information: Hard and Soft, Working paper, Northwestern University, 2004, https://citeseerx.ist.psu.edu/viewdoc/download?doi=10.1.1.126.8246\&rep=rep1\&type=p df.

Petersen, M. A., and R. G. Rajan, 1994, The Benefits of Lending Relationships: Evidence from Small Business Data, Journal of Finance, Vol. 49, pp. 3-37. 
The Impact of Relationship Lending on Bank Loan Process for Korean SMEs

Petersen, M. A., and R. G. Rajan, 1995, The Effect of Credit Market Competition on Lending Relationships, The Quarterly Journal of Economics, Vol. 110 (2), pp. 407-443.

Poirier, D., 1980, Partial Observability in Bivariate Probit Models, Journal of Econometrics, Vol. 12, pp. 209-217.

Rajan, R. G., 1992, Insiders and Outsiders: The Choice between Informed and Arms' Length Debt, Journal of Finance, Vol. 47, pp. 1367-1400.

Sartori, A. E., 2003, An Estimator for Some Binary-Outcome Selection Models Without Exclusion Restrictions, Political Analysis, Vol. 11 (2), pp. 111-138.

Sharpe, S. A., 1990, Asymmetric Information, Bank Lending and Implicit Contracts: A Stylized Model of Customer Relationships, Journal of Finance, Vol. 45, pp. 1069-1087.

Stiglitz, J. E., and A. M. Weiss, 1981, Credit Rationing in Markets with Imperfect Information, American Economic Review, Vol. 71, pp. 393-410.

Udell, G. F., 2008, What's in a Relationship? The Case of Commercial Lending, Business Horizons, Vol. 51, pp. 93-103.

von Rheinbaben, J., and M. Ruckes, 2004, The Number and the Closeness of Bank Relationships, Journal of Banking and Finance, Vol. 28, pp. 1597-1615. 